\title{
LA CONSTITUCIÓN CHILENA DE 1818 (A 200 AÑOS DE SU PROMULGACIÓN)
}

\section{THE CHILEAN CONSTITUTION OF 1818 (AT 200 YEARS OF ITS PROMULGATION)}

\author{
Eric Eduardo Palma González \\ Universidad de Chile
}

\begin{abstract}
SUMARIO: INTRODUCCIÓN. I. LA CONSTRUCCIÓN DEL ESTADO CONSTITUCIONAL EN CHILE (1812-1833). II. EL GOBIERNO DE BERNARDO O`HIGGINS. 1. La dictadura de O`Higgins. 2. El liberalismo político de O`Higgins. III. EL IDEARIO CONSTITUCIONAL DE O`HIGGINS. IV. LA PRÁCTICA CONSTITUCIONAL DEL DIRECTOR SUPREMO: REGULACIONES DE LA CARTA CONSTITUCIONAL DE 1818 Y COMPARACIÓN CON LAS CARTAS CHILENAS DE 1812 Y 1822. 1. Evaluación del texto siglo XIX y XX. 2. Análisis de la normativa constitucional de 1818. 2.1. Dios y orden constitucional, constitución con religión oficial. 2.2. Responsabilidad por infracción de la Constitución y visión de la misma como norma jurídica vinculante. 2.3. Consagración de derechos individuales. 2.4. Consagración de deberes del Estado para con las clases populares, así como de los individuos en la vida social. 2.5. Constitución y nación. 2.6. Constitución sin ciudadanos. 2.7. Constitución sin indígenas. 2.8. Consagración de la libertad de los esclavos (vientres libres). 2.9. Regulación constitucional del cabildo. 2.10. Congreso Nacional unicameral. 2.11. Regulación del derecho constitucional de excepción. 2.12. Reforma Constitucional. 2.13. Constitucionalización del proceso penal. 2.14. Regulación del proceso de creación de ley. 2.15. Posición del Ejecutivo en relación con los demás poderes y órganos estatales. REFLEXIONES FINALES.
\end{abstract}

Resumen: El artículo estudia, desde una perspectiva historiográfica no desarrollada hasta ahora, la Constitución de 1818 promulgada por Bernardo O’Higgins, para lo cual analiza las ideas políticas del prócer, su ideario constitucional, así como la práctica constitucional a través del estudio comparado del texto con las cartas constitucionales chilenas de 1812 y 1822. Dado que propone nuevas interpretaciones, espera contribuir al conocimiento del constitucionalismo chileno del siglo XIX.

Abstract: The article explores a new historiographic perspective on the 1818 Chilean Constitution, promulgated by Bernardo O'Higgins. It dwells on his political ideas, his constitutional ideology, as well as his constitutional practice while offering a comparative analysis with the previous Chilean constitutional documents (1812 and 1822), hoping to contribute to the debate on Chilean 19th century constitutionalism from a new perspective. 


\section{Palabras clave:}

Constitución chilena de 1818, Constitución chilena de 1822, Constitución chilena de 1812, historia constitucional de Chile, ideario político e ideario constitucional de Bernardo O`Higgins.

\section{Key words}

Chilean Constitution of 1818, Chilean Constitution of 1822, Chilean Constitution of 1812, constitutional history of Chile, political ideology and constitutional ideology of Bernardo O'Higgins

\section{INTRODUCCIÓN}

Se han cumplido 200 años de la Declaración de la Independencia de Chile y de la Constitución Provisoria de 1818, ambas, obras del Director Supremo Bernardo O`Higgins. Se trata de una ocasión más que oportuna, para seguir avanzando en el conocimiento y entendimiento del Derecho constitucional del naciente Estado y república independiente de la América del Sur.

El trabajo que presentamos tiene varios objetivos: contribuir al conocimiento del pensamiento constitucional del prócer de la independencia chilena, Bernardo O’Higgins; caracterizar la Constitución de 1818, primera carta fundamental de la República de Chile, a la luz de las ideas políticas y la práctica constitucional que la rodeó; aportar a la comprensión y valoración positiva de la construcción del Estado Constitucional en el Chile del siglo XIX ${ }^{\mathbf{1}}$; valorar en su justa medida los textos que forjaron los órdenes constitucionales de la etapa de 1812-18332.

Compararemos el texto constitucional de 1818 con las constituciones chilenas de 1812 y de 1822 (también de autoría de O`Higgins), para poner de relieve su identidad, así como la transformación que experimentó la propuesta constitucional del Director Supremo producto de la experiencia y el devenir de la actividad política de los 4 años que separan ambos textos fundamentales. Conectaremos tangencialmente dicha experiencia constitucional con el pensamiento y acción política de Simón Bolívar. Configuramos de esta manera una nueva perspectiva de análisis destacándose aspectos no identificados hasta ahora $^{3}$.

Desde el punto de vista metodológico, se trata de una investigación inserta en la Historia Constitucional siguiendo el método y la perspectiva sostenida por

\footnotetext{
1 Este artículo fue escrito en el contexto de las obligaciones del Plan de Fortalecimiento de la investigación de la Facultad de Derecho de la Universidad de Chile.

Agradezco la muy valiosa colaboración del servicio de Biblioteca de la Facultad de Derecho de la Universidad de Chile, en concreto, a Marión García y Carolina Maulén.

2 Existe una visión negativa de esta experiencia, véase por todos, Bernardino Bravo, "E1 primer constitucionalismo en Chile (1811-1861)", Revista de Estudios Histórico-Jurídicos, vol. XV, Valparaíso, Chile, 1992-1993, quien la descalifica: "Por lo que toca a su suerte, estos textos rara vez pasaron de ser papel mojado. Apenas alcanzan vigencia efectiva durante algún tiempo, por lo general, efimero" (p. 305).

3 El trabajo se diferencia de este modo de los análisis clásicos de Orrego Vicuña, Valencia Aravia; Galdames; Carrasco Delgado y Heise que citaremos más adelante.
} 
Eric Palma $(1997,2011)^{4}$ y Joaquín Varela Suanzes-Carpegna (2007, 2008 y $2015)^{5}$.

Esto implica entender la Historia Constitucional centrada en una propuesta jurídico política (concepto sustantivo y axiológico) que aspira a superar el Antiguo Régimen, así como, abandonar el análisis puramente exegético del texto para constatar cómo han variado o se han mantenido en el tiempo las regulaciones; concentrarse en el texto y contexto; en la continuidad y el cambio; en la cultura constitucional y en la comprensión del derecho como producto social.

Utilizamos para el análisis categorías ya propuestas (Palma, 2002, 2004, 2011 , 2012), que conectan las disposiciones normativas con la vida política y los valores e intereses de los actores que cuentan con el poder politico para definir la normativa constitucional, e implican también, distinguir el fenómeno político del constitucional, lo que lleva, por ejemplo, a preguntarse si el desprestigio del gobernante debe significar el desprestigio del texto constitucional que lo acompañó.

Se ha explorado poco, y no es este el momento de hacerlo, la relación entre derogación y constitución: textos constitucionales sustituidos vuelven a ser invocados como si no les hubiese afectado el fenómeno de la derogación (así ocurre con la Constitución de 1818, según veremos), cuestión particularmente relevante cuando la norma constitucional, como ocurrió en el siglo XIX chileno, y presumiblemente en todo el mundo iberoamericano, es tratada como otra norma jurídica más.

La investigación aporta también a la revitalización de la disciplina de la Historia Constitucional ${ }^{6}$. La historiografia constitucional chilena ha sido escasamente cultivada en las últimas décadas (1960-2018). Ni el debate constitucional actual relativo a la asamblea constituyente, ni la celebración del bicentenario de 1810 y de la Constitución de Cádiz de 1812, contrariamente a lo que plantea Fernández Sarasola para otros escenarios (la historia constitucional “"tiende a revitalizarse cuando un país se ve inmerso en procesos constituyentes o de reforma constitucional"7), han logrado revertir en nuestro país este lamentable descuido ${ }^{8}$.

\footnotetext{
4 Eric Palma González, "Reflexiones en torno a una concepción polifacética para una historia del derecho de los siglos XIX y XX”, en Ius et Praxis, Talca, 1997, pp. 325-350; Estado constitucional Liberal Católico en Chile (1812-1924) Nueva Historia Constitucional, $1^{\mathrm{a}}$. edición, Orión. Colección Juristas Chilenos, Santiago de Chile, octubre de 2011, 740 pp.

5 Joaquín Varela Suanzes-Carpegna, "Algunas reflexiones metodológicas sobre la Historia Constitucional", en Historia Constitucional. Revista Electrónica, número 8, 2007, pp. 246-259; Joaquín Varela Suanzes-Carpegna, "Algunas reflexiones metodológicas sobre la Historia Constitucional”, Teoría y Realidad Constitucional, núm. 21, 2008, pp. 411-425. También en Historia e historiografia constitucionales. Madrid: Editorial Trotta, 2015.

6 El artículo se inserta dentro de las explicaciones y tesis sostenidas en numerosas publicaciones del autor. Se reiteran por lo mismo ideas presentadas en anteriores publicaciones.

7 En Joaquín Varela Suanzes-Carpegna, Historia...op. cit., p. 133.

8 Un breve recuento indica que en las últimas décadas dos autores han hecho el mayor número de contribuciones en el desarrollo de la disciplina, ya sea publicando artículos o libros cuyo eje central es la historia constitucional: 1. Sergio Carrasco Delgado ha publicado, entre otras obras; - Génesis y vigencia de los textos constitucionales chilenos, Editorial Juridica de Chile, $1^{\mathrm{a}}$. edic, 1980, 3ª . edic. 2002: -"La crisis politico-constitucional del 11 de septiembre de 1973.
} 
Nos proponemos una breve descripción del Gobierno de Bernardo O`Higgins, primer gobierno no monárquico inspirado en el principio representativo, adentrándonos en su ideario político y práctica política, caracterizada por algunos contemporáneos suyos y por cierta historiografia, como una de tipo dictatorial. Abordaremos la cuestión constitucional describiendo el fenómeno de construcción del Estado constitucional en Chile en la etapa de 1812-1833, para pasar luego a caracterizar el Reglamento Constitucional Provisorio de 1818 a la luz de la normativa constitucional chilena de 1812 y 1822. Este trabajo comparativo nos permite dar identidad al primer texto constitucional del Estado de Chile independiente.

Desde la perspectiva de la Historia Constitucional, distinguimos el ideario político y constitucional, de la práctica político-constitucional, lo que nos permite la construcción de una perspectiva de análisis en que la constitución no queda en la penumbra como consecuencia de la calificación del gobierno como dictatorial: procuramos responder a la pregunta por el valor político e historiográfico de estudiar la actividad politico constitucional de quien ha sido calificado como dictador.

\section{LA CONSTRUCCIÓN DEL ESTADO CONSTITUCIONAL EN CHILE (1812- 1833) ${ }^{9}$}

En la primera mitad del siglo XIX se dictaron en Chile un número relevante de constituciones, transformándose esta época en un momento de enorme relevancia para la historia constitucional: se consolidó la opción por regular el estado naciente como república y como estado constitucional. Cabe recordar al respecto lo declarado en el Acta de Independencia: “...el territorio continental de Chile y sus islas adyacentes, forman de hecho y por derecho, un Estado libre, independiente y soberano, y quedan para siempre separados de la Monarquía de

antecedentes y consecuencias", en Revista de Derecho de la Pontificia Universidad Católica de Valparaíso XXV, 2004; - "La evolución político-constitucional de Chile", en Estudios Constitucionales, vol. 6, núm. 2, 2008, pp. 301-324 Centro de Estudios Constitucionales de Chile Santiago, Chile. 2. Eric Eduardo Palma González, ha publicado, entre otros trabajos: - “¿Gobierno portaliano o Gobierno conservador-autoritario? De los mecanismos constitucionales para garantizar la eficacia del ejercicio del poder en la Constitución de 1833", en Revista de Derecho, volumen XIII, Facultad de Ciencias Jurídicas y Sociales, Universidad Austral de Chile, diciembre 2002; - La Constitucionalización del proceso penal en Chile y sus alcances en la doctrina y la práctica procesal del siglo XIX, Colección de Investigaciones Jurídicas, Universidad Alberto Hurtado, 2004; - “De la Carta Otorgada de 1980 a la Constitución Binominal de 2005”, en revista Derecho y Humanidades, número 13, pp. 41-66, Santiago de Chile, 2008; - Tareas Legislativas del Poder Judicial, editado por el Poder Judicial de la Federación. Suprema Corte de Justicia de la Nación, México, 2010; - Estado constitucional Liberal Católico en Chile (1812-1924) Nueva Historia Constitucional, $1^{a}$. edición, Orión. Colección Juristas Chilenos, Santiago de Chile, octubre de 2011, 740 pp; - Estado constitucional Liberal Católico en Chile (1812-1924) Nueva Historia Constitucional, $2^{a}$. edición, Facultad de Derecho, Universidad de Chile. LOM impresiones, Santiago de Chile, marzo 2012, 743 pp. - "36 años demandando Asamblea Constituyente (19792015)", en Manuel Fernández Gaete, Cristián Figueroa Claude, editores, Fumando Opio, editorial Mutante, 2015, pp. 142-158; - "Abolición de la esclavitud en el constitucionalismo del siglo XIX: Colombia, Chile, Perú y Portugal, coord., Editorial Jurídica de Chile, 2016.

9 Seguimos de cerca lo explicado en Eric Eduardo Palma, Estado Constitucional Liberal Católico, ob. cit. 
España, con plena aptitud de adoptar la forma de Gobierno que más convenga a sus intereses"10.

Como se ha señalado, la elite criolla no consolidó en la etapa 1810-1828 una forma de gobierno, pero, logró afianzar la nueva fórmula de arreglo del poder político: en medio de la guerra de independencia, y de las guerras civiles que se sucedieron en el seno de los independentistas, consolidó la opción por el Estado constitucional. Se resolvió en este marco político-normativo si la incipiente república avanzaría hacia una forma de Estado unitario o federal; un gobierno monárquico o republicano, centralizado - descentralizado, de ejecutivo fuerte o equilibrado con el congreso, de concentración de poderes o funciones o de división de las mismas.

Este periodo por lo tanto es de una enorme importancia para la historia republicana pues constitucionalizó la vida nacional.

Entre 1810 y 1833 las numerosas constituciones presentan continuidades normativas, dando lugar a la consolidación de un mínimo común constitucional $^{11}$ : la consagración del gobierno representativo y no hereditario; del principio de división de poderes; la consagración del pueblo (1812) o de la nación $(1818,1822,1823,1828,1833)$ como titular de la soberanía; la regulación de la religión católica como oficial del Estado; el establecimiento de la responsabilidad de las autoridades públicas por violación de la constitución; la consagración de un cuerpo electoral sobre bases o criterios censitarios, lo que implicaba excluir de la ciudadanía a las masas campesinas y a los sectores económicamente débil; la consagración de ciertos derechos individuales y la regulación del proceso penal ${ }^{12}$.

El consenso implicó avanzar en una nueva forma de concebir el origen y el ejercicio del poder público, configurándose un entramado de reglas relativas a la ejecución de la voluntad política, cuyo efecto más significativo fue el intento de control, por la elite santiaguina y provinciana, de los lideres políticos.

Su relevancia también radica en que:

"Este mínimo común constitucional fue el antídoto en Chile del caudillismo, cuya existencia como fenómeno sociopolítico es más bien efimera. La acción de los grupos, de los colectivos, el corporativismo o gremialismo indiano expresado en la acción de los cabildos, implicó un

10 Universidad de Concepción, Acta de la Independencia de Chile, 1978, p. 28

11 Además de las constituciones de 1812, 1818, 1822, 1823, 1828 y 1833, se promulgaron textos que abordaban temas constitucionales: Reglamento de la autoridad Ejecutiva de 1811; Reglamento de la Autoridad Ejecutiva de 1814; Acta de Unión de las Provincias de 30 de marzo de 1823; la ley Federal de 1826; y la ley de 14 de Febrero de 1827 que reguló las atribuciones del Poder Ejecutivo.

12 La Carta de 1822 señala en su preámbulo: "El Código que os presentamos contiene dos partes. La una abraza los principios fundamentales e invariables, proclamados desde el nacimiento de la revolución, tal es: la división e independencia de los poderes politicos, el sistema representativo, la elección del primer Magistrado, la responsabilidad de los funcionarios, las garantias individuales".

Trabajamos con las versiones de las constituciones según la publicación, Constituciones Políticas de la República de Chile 1810 - 2005, Primera Edición (2005), Editado por el Diario Oficial de la República de Chile. 
límite al personalismo y al individualismo: Carrera, O'Higgins, Irisarri y Freire debieron enfrentar a estas fuerzas que entendieron tempranamente que se debía ejercer el poder sujeto a reglas estables y permanentes con reconocimiento expreso de los derechos que le interesaban de manera particular, a saber, la propiedad, la libertad económica, la participación aunque censitaria-, la educación, la libertad y la seguridad individual"13.

La historiografia que se ha venido ocupando de la actividad política de O’Higgins, no repara en el hecho que la figura del dictador que ellos han construido, impide detenerse en el rol jugado por las constituciones que promulgó. En la medida que el prócer aceptó promulgar dos textos constitucionales, bajo presión por cierto del patriciado capitalino, su capacidad de obrar como mero caudillo sometido sólo a las reglas de la política se vio mermada ${ }^{14}$. Rescatable es en este sentido, la disputa del Director Supremo con el Senado Conservador, que la mayoría de las veces implicó la derrota de O`Higgins. Orrego señala a este respecto: "El Senado habría de despertarlo de su sueño absoluto y traerlo bruscamente a la realidad de la vida republicana en que todas las tareas directivas se distribuyen con equidad entre los organismos constituidos del Estado"15.

Al generar la máxima autoridad un campo normativo para ordenar la relación entre el Estado y los individuos, entre el Estado y la sociedad, y entre los mismos individuos, y que daba luces de qué es lo que cabía esperar del "orden político liberal" (Constitución Provisoria de 1818), o de las reglas permanentes (Constitución de 1822), canceló el libre accionar del caudillismo'b.

Orrego Vicuña reproduce la opinión vertida en el periódico El Sol respecto de la promulgación de la carta de 1818: "Vale más contar con un código que con ninguno; y el actual puede ser muy bien la piedra angular del majestuoso templo de la libertad de Chile. Plantemos, pues, el estandarte constitucional, y forjaremos una falange invencible, reuniéndonos alrededor de él todos cuantos prefieran la libertad a la esclavitud, el honor a la infamia"17.

13 Eric Eduardo Palma, Estado Constitucional Liberal Católico, op. cit., p. 367

14 El propio O`Higgins en agosto de 1826, en carta dirigida a John Doyle (con quien planificó la llegada de colonos irlandeses a Chile) señaló a este respecto: "Más tarde supe que Freire, obligado por la mayoría del pueblo, tuvo que llamar a un Congreso que se abocara a la dictación de otra Constitución que reemplazara a la que había abolido...El Congreso que convocó de alguna manera, no fue enteramente instrumento de su gobierno y vetó muchas de esas arbitrariedades, razón por lo cual nuevamente la fuerza actuó. El Congreso fue suprimido en mayo de 1825, igual como lo había sido antes el Senado Conservador" (en Epistolario de don Bernardo O`Higgins. Tomo I., op., cit., p. 395).

15 Eugenio Orrego Vicuña, El espíritu constitucional de la Administración O`Higgins, Imprenta Cervantes, Santiago de Chile, 1924, p. 58

16 Casimiro Albano, Memoria del Excelentísimo señor don Bernardo O`Higgins. Capitán General de la República de Chile, Brigadier en la de Buenos Aires, Gran Mariscal en la del Perú y Socio Protector en la Sociedad de Agricultura, Imprenta de la Opinión, 1844, p. 44, señala en este sentido refiriéndose a la carta constitucional de 1818 :”...volver a la nación un poder tan peligroso, para que fijase, por una carta cualesquiera, aunque fuese provisional, la esfera en que debia marchar su Gobierno".

Tanto respecto de este texto como de los del siglo XIX no respetaremos la grafia propia de la época, sino que la actualizaremos.

17 Luis Orrego Vicuña, El espíritu constitucional, op. cit., p. 51 
Cabria pensar entonces en una suerte de tránsito desde la forma de gobierno dictatorial al caudillismo, que fue orientada en cierta medida por el surgimiento de una cultura constitucional que terminó poniendo trabas institucionales a ambas figuras, transformándose, para el caso chileno, en figuras de excepción.

Pero aceptar estas ideas requiere también reconocer a las constituciones de 1818 y de 1822 un cierto grado de obligatoriedad, cuestión que todavía cierta historiografia nacional se resiste a aceptar ${ }^{18}$, así como comprender el radio de acción de la normativa constitucional en la vida social, política, económica y cultural de la incipiente república y Estado independiente. Las regulaciones resolvian cuestiones sustantivas de la vida en sociedad, ellas conformaban la "Ley Fundamental" de todo Estado bien organizado.

\section{EL GOBIERNO DE BERNARDO O`HIGGINS}

La crisis de la Monarquía Española desató el proceso de independencia, e implicó enfrentar, para quienes condujeron la guerra y el nuevo poder político, el desafio de crear un orden institucional para una sociedad que terminó condenando la forma monárquica de gobierno y avanzó a la conformación de un gobierno representativo. Fórmula que carecía de arraigo suficiente incluso entre algunos lideres de las guerras de independencia, que veían en la Monarquía la única posibilidad de garantizar orden y prosperidad en las nacientes entidades políticas. Cabe recordar que el Reglamento Constitucional Provisorio de 1812, dictado por José Miguel Carrera, consagraba la posibilidad de una Monarquía Constitucional para Chile. Ninguno de sus artículos se refirió expresamente a la situación del Reino de Chile como república independiente. En este sentido la carta constitucional de 1812 es la primera y última del Reino de Chile ${ }^{19}$.

Bernardo O’Higgins ocupó el cargo de jefe de estado o Director Supremo, entre el 16 de febrero de 1817 y el 23 de enero de 1823, asumiendo la responsabilidad de consolidar la separación definitiva de la Monarquía, declarar

18 Desde el punto de vista de la historia institucional, que no constitucional según la óptica que compartimos con Joaquín Varela Suanzes-Carpegna (Q.E.P.D.), Bernardino Bravo es majadero, en varias de sus obras, en negar eficacia y valor a las constituciones en el rol de ordenación de la sociedad: "Estas constituciones de papel, se deshacian como agua entre las manos. Peor que su proliferación fue su falta de duración y de eficacia. De hecho, ninguna permaneció en el tiempo. Todas tuvieron corta vigencia, tras la cual fueron a parar al canasto de los papeles. En rigor, más que constituciones de papel, esto es, desechables, fueron una suerte de telón de teatro; montados y desmontados con la misma facilidad que una escenografia. Al igual que ella, pasaron simplemente, sin pena ni gloria. No aportaron nada a la estabilidad del país, antes bien sembraron la discordia y la inseguridad" ("El estado en Iberoamérica (siglos XVI al XXI). panorama histórico: jurisdicción, administración y monocracia", en Revista Chilena de Historia del Derecho, $\mathrm{N}^{\circ} 24$ / 2013-2014, pp. 191-335, p. 226).

Una opinión distinta y contrapuesta en Antonio Dougnac, "El sistema jurídico indiano en el constitucionalismo chileno durante la Patria Vieja (1810-1814)", en Revista de estudios históricojurídicos. n.22, Valparaíso 2000, pp. 225-266

19 Eric Eduardo Palma, Estado Constitucional Liberal Católico en Chile (1812-1924) Nueva Historia Constitucional, $2^{\mathrm{a}}$. edición, Facultad de Derecho, Universidad de Chile. LOM impresiones, Santiago de Chile, 2012, pp. 252 y ss. 
oficialmente la independencia del Estado de Chile ${ }^{20}$, así como dar forma al nuevo orden politico institucional que vino a inaugurar el estado constitucional chileno. $\mathrm{Su}$ Gobierno se caracterizó por organizar la seguridad externa de la república, combatiendo la amenaza española que operaba desde el virreinato y desde la Isla de Chiloé, así como por enfrentar la resistencia que generaron sus medidas en la Iglesia, el tradicional patriciado y el grupo político dirigido por los hermanos Carrera $^{21}$.

Se le ha caracterizado como un Gobierno realizador a pesar de la coyuntura de la guerra independentista, destacando su contribución en obras públicas, fundación de pueblos, fomento del comercio interno e internacional. En materia de educación se ocupó del Instituto Nacional y de fomentar la educación pública. Incluso, como nos recuerda Orrego, se dictó una ley de matrimonio civil. Se reformó la administración al prohibir la venta de cargos y ordenar que sólo el mérito fuese tenido a la vista para decidir quién debía ocuparlos. Abolió los títulos de nobleza y prohibió la fundación de mayorazgos. Y lo más relevante para los intereses de Chile y de todo el Cono Sur, organizó la escuadra libertadora del Perú22.

El 28 de enero de 1823 ante el alzamiento del ejército del sur al mando de Ramón Freire, quien mantenía graves diferencias con el Ministro José Antonio Rodríguez pues desatendía las demandas económicas de Concepción, la elite santiaguina con el argumento de evitar una guerra civil, obligó a O'Higgins a abdicar. Generaban efecto las acusaciones de autoritarismo y de no haberse respetado la voluntad popular en la gestación del texto constitucional de $1822^{23}$.

Manifestación de dicha acusación es la temprana obra de Manuel Amunateguí, quien legó a la posteridad la calificación de su gobierno como dictadura: "El argumento principal de este libro es la historia de las tentativas que hizo sin fruto el capitán general don Bernardo O’Higgins para establecer en Chile la dictadura. La conclusión que se deduce de los hechos referidos en esta obra es la imposibilidad de implantar en América de un modo durable esa forma de Gobierno"24.

La Junta que sucedió al Director Supremo declaró abolida la Constitución de 1822. Sin embargo, las elites de las provincias de Coquimbo, Concepción y Talca

20 Para un análisis reciente de la dimensión politica de la declaración de la independencia, véase con provecho a Cristián Guerrero Lira, Ulises Cárcamo Sirguiado, 1818 La proclamación de la Independencia de Chile. Historia y Memoria, Realidad y Mito, editorial Historia Chilena, Santiago de Chile, 2018.

21 Para el acontecer político del gobierno de O`Higgins, véase por todo el excelente trabajo de Luis Galdames, La evolución constitucional de Chile, imprenta Ballcels y Co, Santiago de Chile, 1925.

22 Para una detallada cuenta de su vida y su acción en el campo de batalla y en el Gobierno, contamos con el siempre interesante estudio de Benjamín Vicuña Mackenna, Vida del Capitán General don Bernardo O`Higgins, editado en 1882. Existe una versión más reciente editada por la Editorial del Pacífico, Santiago de Chile, 1976, 675 pp.

23 Luis Galdames, La evolución constitucional... op. cit., pp., 569 y ss.

Luis Valencia Avaria considera que no hubo intervención electoral ("Orígenes politico sociales de las constituciones de O`Higgins, Revista de Derecho Público, núm. 23, 1978, pp. 25-35).

${ }^{24}$ Miguel Luis Amunategui, La Dictadura de O`Higgins, Imprenta. Litografia y Encuadernación, Barcelona, Santiago de Chile, 1853. 
desconocieron dicha Junta y nombraron plenipotenciarios. E1 30 de mayo del año 1823 firmaron los plenipotenciarios el "Acta de Unión de las Provincias". El acuerdo respecto del régimen de Gobierno contempló la formación de un Senado Conservador de 9 miembros -3 por Santiago, Coquimbo y Concepción- que vino a reemplazar al Congreso y a la Junta ${ }^{25}$. En mayo de 1823 se hizo cargo del Gobierno un nuevo Director Supremo y de la función legislativa un Senado. Se dispuso que rigiera la acción de ambos poderes la Constitución de 1818.

\section{La dictadura de $\mathbf{O}^{\prime}$ Higgins}

¿Cuál es el valor para la historia constitucional de caracterizar el ideario y práctica constitucional de quien ha sido calificado como dictador por parte de la historiografia nacional ${ }^{26}$ ?

Valencia Aravia ${ }^{27}$, sostiene que el cabildo de Santiago le ofreció a O`Higgins, al momento de asumir el cargo de Director Supremo, la posibilidad de instaurar una dictadura si así lo estimaba necesario ${ }^{28}$. En estricto rigor el Cabildo pensó en esta fórmula para San Martín. En el comunicado que le dirigió Francisco Ruiz Tagle, Gobernador Político Interino del Reino de Chile, se señalaba:

"Me congratulo V.E., como todos los ciudadanos, de haber recaído esta la elección en su dignísima y heroica persona, a cuya inteligencia, celo y constancia debemos nuestra libertad de los fieros tiranos que tan duramente nos oprimían; asimismo esperamos que bajo los auspicios del gobierno de V.E. este reino alcanzará notable progreso.

Es incumbencia de V.E. designar el sistema de gobierno que observará: si la dictadura que es el que más conviene en este momento, o si la república absoluta, todo lo cual deberá comunicarme V.E. para anunciarlo al pueblo libre y entregar a la brevedad posible la suma del poder a V.E. con que mis ciudadanos me han investido interinamente"29.

Al día siguiente, 16 de febrero de 1817, y ante la negativa de San Martín de asumir el cargo, "aclamó el pueblo por Director Supremo interino al señor Brigadier don Bernardo O`Higgins...-quien tomó posesión previo juramento de-

25 Luis Galdames, La evolución constitucional... op. cit., p. 571

26 No nos haremos cargo en este trabajo de la ligazón que hizo la dictadura militar de Augusto Pinochet con la figura de Bernardo O`Higgins, sin embargo, conviene advertir al lector que no cabe hacer una vinculación automática entre la experiencia de la guerra de la Independencia y la dictadura de la etapa 1973-1990.

Cabe hacer notar que no sólo la derecha politica autoritaria simpatiza con O`Higgins, también la izquierda (véase para este asunto de Cristián Guerrero Lira, Ulises Cárcamo Sirguiado, "Bernardo O`Higgins entre izquierda y derecha Su figura y legado en Chile. 1970-2008", en Cuadernos de Historia núm. 39, diciembre 2013, pp. 113-146).

27 Luis Valencia Aravia, "Apuntes sobre la Política Constitucional de O`Higgins", Boletín de la Academia Chilena de la Historia, núm., 60, 1959, p.111

28 La misma idea en Casimiro Albano, Memoria del Excelentísimo señor don Bernardo O`Higgins, op. cit., p. 43, quien afirma que la "nación le había investido con todas las facultades de un Dictador...reposaba con la mayor confianza en este poder sin limites".

29 Archivo de don Bernardo O`Higgins. Tomo VII. Editorial Universitaria, Santiago de Chile, 1950, p. 160 
...usar bien y fielmente del cargo de Director Supremo interino del pueblo libre de Chile, defendiéndolo y amparándole en su libertad"30.

Conviene precisar que Amunategui no sostuvo que O`Higgins fuese un dictador. Lo que afirmó en su célebre obra de 1853 es lo siguiente: "Pues bien, O’Higgins dio indicios, solamente indicios, de aspirar a la dictadura, i experimentó la caída más miserable de que haya ejemplo en nuestra historia"31.

Sin embargo, según él mismo, luego de la victoria patriota de abril de 1818 en los campos del Maipo:

“...muchos vecinos creyeron que la independencia estaba ya asegurada, i que la dictadura en adelante era innecesaria.

Comenzóse a hablar con calor en los círculos de la capital sobre la urgencia de poner término al régimen militar i absoluto que se hallaba establecido. Se clamó porque de una vez se afianzasen las garantias de los individuos, y se tomasen precauciones contra los desafueros posibles de la autoridad. Era ya preciso que se proveyese al respeto a las propiedades; que se atendiese a la seguridad de las personas; que se fijasen las reglas al ejercicio del poder; que se diese intervención al pueblo en el gobierno"32.

Califica entonces a O`Higgins, como un dictador al que se presentó por una comisión de vecinos del cabildo de Santiago la exigencia de fijar reglas al ejercicio de su poder. Afirma que incluso sus cercanos comprendian que: "A la dictadura arbitraria y sin restricciones de ningún género que existía, debía sustituirse una dictadura legal" -añadiendo que- "O`Higgins reconoció la justicia de estas observaciones" 33 , sin embargo, califica su gestión antes de la promulgación de la Constitución de 1818, como "dictadura militar"34.

Orrego Vicuña afirma:

"El gobierno directorial, severo en su política, autoritario, disciplinario en extremo en un tiempo en que la menor relajación equivalia a marchar al abismo, habia lesionado intereses y levantado odios inevitables. Los patricios ansiaban una participación de primer plano en la administración y los caudillos populares, a cuya cabeza se halló Manuel Rodríguez, exigian lo mismo"35.

Según Heise, ante los aristócratas aparecía como un peligroso innovador y ante los exaltados e idealistas soñadores, como un dictador ${ }^{36}$.

\footnotetext{
30 Archivo de don Bernardo O`Higgins. Tomo VII, op. cit., p. 161

${ }^{31}$ Miguel Luis Amunategui, La Dictadura, op. cit., p. 27

32 Miguel Luis Amunategui, La Dictadura, op. cit., p. 238

${ }^{33}$ Miguel Luis Amunategui, La Dictadura, op. cit., p. 251

34 Miguel Luis Amunategui, La Dictadura, op. cit., p. 364

35 Eugenio Orrego Vicuña, O`Higgins. Vida y Tiempo, editorial Losada S.A., Buenos Aires, 1957, p. 184

36 Julio Heise, , O`Higgins forjador de una tradición democrática, s.e., 1975, Santiago de Chile, p. 67
}

La muerte de los hermanos Carrera y el asesinato de Manuel Rodríguez, fenómenos en los que se involucra al prócer, justificaba la tenaz oposición del sector denominado como exaltado. 
Amunategui describe al gobierno de O`Higgins como una administración que "comprendió facultades omnímodas, arbitrariedades, secuestros, proscripciones, suplicios" 37 . Sin embargo, dice, sus méritos en la guerra de independencia y su contribución a la libertad de Chile y de sus vecinos, "compensó para muchos la deformidad de su despotismo. El afecto que se profesaba al libertador acallaba en más de un corazón el odio que se debía al dictador"38.

Amunategui induce a error al atribuir a O`Higgins el deseo de instaurar la dictadura. Fue el propio patriciado santiaguino el que puso e incluso recomendó la dictadura como forma de gobierno (que consideraba en la coyuntura de 1817 como preferible a la república absoluta). O`Higgins no renunció a esa suma máxima de poder y lo ejerció contra sus "enemigos" internos y externos, generando en la dialéctica del ejercicio del poder una reacción que llevó a la elite santiaguina y de Concepción a revisar la decisión de haberle entregado todo el poder.

En el proceso de independencia la relación entre dictadura, gobierno autoritario y Derecho, es estrecha: se requiere conformar un orden jurídico que de forma al Estado y la república, todo lo cual ocurre en medio de una guerra que se lleva adelante en la óptica de los óhigginistas, contra poderes externos e internos (calificados como facciones que generaban anarquía y una guerra civilis9) y que provoca que el ejercicio del poder fuese asunto más político que jurídico, de ahí la actuación del poder a la manera dictatorial.

En el año de 1826, O`Higgins en carta de descargo ante severas acusaciones en su contra proferidas en la prensa argentina, luego de describir la violencia política protagonizada por realistas y chilenos contrarios a su Gobierno, afirmó: "He tenido que enfrentarme con hombres a quienes el asesinato (en cualquier forma) era familiar $\mathrm{y}$ quienes se hallaban incansablemente ocupados en conspirar, tramando mi muerte, mientras yo estaba al frente de mi ejército y del gobierno del país, y mientras ejercía un poder dictatorial, sin embargo, puedo decir honradamente que jamás chileno alguno se vio de luto por mi culpa"40.

Cabe recordar que Francisco de la Lastra, luego de dictado el Reglamento Constitucional, promulgó como Director Supremo el 17 de marzo de 1814, el Reglamento para el Gobierno Provisorio. Disponia su artículo primero concentrar el Poder Ejecutivo en una persona con el título de Director Supremo, residiendo en él las absolutas facultades que ha tenido la Junta de Gobierno en su instalación de 18 de septiembre de 1810. Agregaba el artículo $2^{\circ}$ : "Por tanto, sus facultades son amplísimas e ilimitadas, a excepción de tratados de paz,

37 Miguel Luis Amunategui, La Dictadura, op. cit., p. 263

38 Miguel Luis Amunategui, La Dictadura, op. cit., p. 264

39 Evaluando el accionar de sus opositores escribía en 1826 en carta dirigida a Bernardino Rivadavia: "Tales ataques son la justa recompensa que espera todo hombre honesto al entrar en la vida pública durante un periodo de guerra civil, un periodo en el que se desencadenan todas las malas pasiones que alienta el corazón humano. Es entonces cuando son estimuladas y, en vez de controlar esos sentimientos, los hombres se ven arrastrados por sus innobles impulsos cometiendo las peores vilezas-. De aquí que suceda tan a menudo, durante tales épocas, que aquel que más servicios presta a su patria, es el más calumniado" (en Epistolario de don Bernardo O`Higgins. Tomo I. editores Alfredo Gómez Alcorta, Francisco Ocaranza, ediciones Universidad Bernardo O`Higgins, Santiago de Chile, 2011, p. 398)

40 Epistolario, Tomo I., op. cit., p. 423 
declaraciones de guerra, nuevos establecimientos de comercio, y pechos o contribuciones públicas generales, en que necesariamente deberá consultar y acordarse con su Senado".

Dotado O`Higgins de la máxima autoridad que se le entregó por decisión del Cabildo de 16 de febrero de 1817, aprobó el denominado Plan Provisorio de Hacienda y Administración Pública, que Valencia Aravia (1959, 1978) y Eyzaguirre (1965) consideran como un texto con rasgos constitucionales, debiendo gobernar a partir del 2 de septiembre de 1817 con un Tribunal Superior de Justicia y Apelación diferenciado del ejecutivo.

No se ve por parte de O`Higgins que exista una contradicción entre pretender gobernar dictatorialmente en medio de una guerra civil, y promulgar una constitución, incluso si esta es provisoria, porque de lo que se trata es de ejercer la soberanía y dar señales al pueblo de lo que cabe esperar del nuevo orden de cosas una vez alcanzada la total independencia, y terminada la guerra y la situación de anormalidad.

Se entendía que la dictadura no habilitaba para la sustitución del soberano, ni habilitaba para conformar el nuevo orden de cosas, sino, para consolidar la independencia que haría posible la manifestación del soberano.

Vista la cuestión desde el derecho de excepción, parece que la elite consideró la situación de anormalidad como lo suficientemente grave para entregar todo el poder a una "autoridad electa" para ejercer la dictadura. Dictadura que es calificada por el Cabildo como "forma de Gobierno", por ende, dictadura a la manera romana ${ }^{41}$.

Bolivar demostró años más tarde que la dictadura no se concebía como contradictoria con la revolución de la independencia. Ella, acompañada por el Derecho, venía a garantizar el éxito de una empresa destinada a preservar la revolución y su ideario. Tal como la concibió, se trataba de una fórmula que facilitaba la construcción de un tipo de Gobierno que limitaba los efectos de la democracia popular y los de un gobierno despótico.

Rey González nos recuerda la visión del Libertador: "La dictadura, con su omnipotencia, fundirá todos los partidos y los hará entrar en el silencio; después se debe consultar la voluntad nacional para saber qué quiere; luego es preciso hacer lo que ordene el soberano...La dictadura ha sido mi autoridad constante... Esta magistratura es republicana; ha salvado a Roma, a Colombia y al Perú... Jamás un Congreso ha salvado a una República"42.

O’Higgins no pareció disentir de esta fórmula bolivariana. En 1824, al saludar a Bolivar por su accionar, celebraba que hubiese sido elevado a la calidad

41 Juan Luis Ossa estudiando la visión de cinco agentes norteamericanos, relata que según alguno de ellos el gobierno de O`Higgins miraba la experiencia europea y la dictadura romana. La mayoría describía como trato despótico el que daba a la oposición organizada en torno a los hermanos Carrera ("El gobierno de Bernardo O'Higgins visto a través de cinco agentes estadounidenses, 1817-1823”, en revista Co-herencia, vol. 13, núm. 25, julio-diciembre, 2016 , pp. 139-166).

42 Juan Carlos Rey González, "De la ilusión republicana a la realidad personalista. Análisis de las ideas, la legislación y la acción en torno a la dictadura y los estados excepcionales a partir del pensamiento de el Libertador", Anuario de Estudios Bolivarianos, año XII, número 13, 2006, pp. 91-134 
de "Supremo Dictador del Perú"43, lo que había ocurrido por ley de septiembre de $1823^{44}$.

Evaluando la experiencia de la guerra de independencia en la América Hispana y la construcción de los nuevos estados, Rodríguez, concluye:

"A pesar de las luchas por el poder, como las que se dieron entre monarquistas y republicanos, centralistas y federalistas, parlamentaristas y caudillos, un gobierno liberal, representativo y constitucional permaneció como el ideal político de las naciones de habla hispana. De hecho, aun los caudillos y los dictadores se han visto forzados a reconocer, por lo menos en principio, la supremacía del gobierno de la ley y el desiderátum final de un gobierno civil, representativo y constitucional" 45 .

Conviene recordar la distinción de la época entre tiranía y dictadura, cuestión que no desarrollaremos aquí en toda su extensión, pero que permite entender el alcance de la figura política del dictador ${ }^{46}$. Los chilenos, como hizo notar el propio O’Higgins en el Manifiesto a las naciones con ocasión de la declaración de la Independencia, rechazaban seguir sometidos a una tiranía y al tirano español. Régimen que se caracterizaba por su desconocimiento de los derechos individuales y el derecho de la sociedad chilena a la felicidad y goce de los bienes que producía el territorio. La dictadura que el Cabildo concibe como posibilidad política no es la tiranía española, ni el Director Supremo un tirano. La tiranía no es una forma de Gobierno sino una grave desviación de poder descrita por los autores medievales y modernos, y claramente diferenciada de la dictadura como fórmula jurídica de excepción determinada por el estado de necesidad.

La visión del Director Supremo O’Higgins como dictador, y en el que tiene una importante responsabilidad Amunategui, no se construyó basada en esta perspectiva que distingue tiranía de dictadura. Incluso, como hemos visto, es

43 Epistolario, Tomo I., op. cit., pp., 361-362

Para una comprensión del fenómeno de las constituciones peruanas de 1823 y 1826 en relación con el accionar de Bolivar, véase con provecho de Carlos Ramos, La Letra de La Ley. Historia de las Constituciones del Perú, Centro de Estudios Constitucionales, Tribunal Constitucional del Perú, Lima, 2018; también de Valentín Paniagua Corazao, "La Constitución de 1828 y su proyección en el constitucionalismo peruano", en Historia Constitucional (revista electrónica), n. 4, 2003.http://hc.rediris.es/04/index.html; y del mismo autor "E1 proceso constituyente y la constitución vitalicia (bolivariana) de 1826 (II)", en Historia Constitucional (revista electrónica), n. 9, 2008. http://hc.rediris.es/09/index.html

44 Abraham Siles Vallejos, en "La emergencia en el corazón del constitucionalismo peruano: paradojas, aporias y normalización”, en THĒMIS, Revista de Derecho 67. 2015. pp. 73-84, señala; "De esta manera, la naciente República y su flamante orden constitucional quedaron supeditados al ejercicio de un poder omnímodo, que se confería al Libertador en razón de la gravedad de la situación bélica que padecía el país” (p. 80).

45 Jaime E. Rodríguez O, La independencia de la América Española, Editorial Fondo de Cultura Económica, $2^{\text {a }}$. ed., y reimpresión, 2010, p. 425

46 Véase por todos, Maria Victoria Crespo, "Del republicanismo clásico a la modernidad liberal: la gran mutación conceptual de la dictadura en el contexto de las revoluciones hispanoamericanas (1810-1830)", en Prismas, Revista de historia intelectual, N 17, 2013, pp. 6787, Argentina. También con provecho Javier Fernández Sebastián, (Director), Diccionario político y social del mundo iberoamericano La era de las revoluciones, 1750-1850 Fundación Carolina Sociedad Estatal de Conmemoraciones Culturales Centro de Estudios Politicos y Constitucionales. Madrid, 2009 
contradictoria o por lo menos poco diáfana ¿Fue O`Higgins un dictador-tirano? Dar respuesta a esta pregunta implicaría desviar la atención de lo que consideramos central en este trabajo. En todo caso, conocer el pensamiento constitucional del prócer y su manifestación en los textos constitucionales que impulsó, permite presumir que O’Higgins no era un tirano a la manera española. El acto mismo de su abdicación, teniendo la capacidad militar de resistir, implicó una sujeción a la voluntad del patriciado santiaguino evitando con ello una guerra civil. Esta decisión no facilita su calificación como tirano.

Casimiro Albano hizo ver en 1844, que O`Higgins aceptó el juicio de residencia a que fue sometido luego de su abdicación, a sabiendas que era contrario a la Constitución que lo eximía de la aplicación de todo mecanismo de responsabilidad.

Frente a estas miradas historiográficas, sostenemos que la incipiente cultura constitucional que estaba emergiendo en medio de la guerra civil de la independencia, condenó la figura del tirano, aunque permitió el accionar de la figura del dictador, que derivó en caudillo, dejando en claro su carácter de excepcional y la necesidad de que el prócer, superada la contingencia de la guerra, se sometiera también a ciertas reglas. El estado constitucional, creatura de la guerra civil de la independencia, era el territorio político prometido de las libertades y la felicidad, que se alcanzaría en plenitud en tanto en cuanto dictadores y caudillos fueran puestos en cintura.

\section{E1 liberalismo politico de O`Higgins}

La guerra de la independencia y el hecho que la solución a los conflictos por el tipo de Estado y de Gobierno tuviera un importante componente militar, implicó que su relación con la oposición fuese en definitiva antidemocrática e incluso contraria al ideal republicano del debate de las diferencias ante la opinión pública. Privadamente, aceptó combatir a sus enemigos politicos con todas las armas propias de la guerra. En privado y en público condenó las divisiones generadas por las facciones y la anarquía consecuente: en carta fechada en mayo de 1824 señalaba:

"No obstante, es alarmante, mi amado general, el cuadro funesto que nos presenta el desgraciado Chile, no tanto por nuestros enemigos comunes, cuanto por ese peso insoportable de las facciones que lo despedazan y le hacen sentir el peligro de esa efervescencia tumultuosa que ha desnaturalizado sus mejores aptitudes y precipitándolo a la degradante situación de no encontrarse seguridad ni garantía" 47 .

47 Carta al señor Presidente, Libertador de Colombia y Dictador del Perú, en Epistolario, Tomo I., op, cit., p. 366

Idea que reitera en numerosos ocasiones, v.g. en agosto de 1825 en carta dirigida al mismo Libertador señala: "Es tan sensible como cierto el desorden de Chile, mi patria infeliz, y muy repetidos los clamores de hombres de la primera consideración por una reforma que las salve del incendio civil que los abrasa en la efervescencia de pasiones tumultuarias y de facciones encarnizadas que se agitan incesantemente por destruirse mutuamente, no alcanzando remedio a tan grave mal toda la fuerza de la opinión pública, ni el apoyo de las tropas, con excepción de las de Concepción, que no han tenido oportunidad de expresar su opinión" (en Epistolario, Tomo I., op., cit., p. 382). 
La literatura historiográfica es conteste en caracterizar al prócer como un hombre de ideas politicas modernas e ilustradas ${ }^{48}$, nacidas al alero de Francisco de Miranda ${ }^{49}$ con quien coincidió en su estadía en Londres y del cual recibió, según Arrau, su antiespañolismo, las ideas de independencia y de república, el americanismo y la valoración de los cabildos como instancia política con potencialidad para neutralizar el asambleísmo espontáneo ${ }^{50}$.

En 1811 citando la Constitución de los Estados Unidos alababa en concreto la siguiente oración:

“...y para que puedan ser reconocidos los grandes y esenciales principios de la libertad y libre Gobierno, e inalterablemente establecidos, declaramos que todos los hombres somos nacidos igualmente libres e independientes y tenemos ciertos inherentes e inviolables derechos entre los cuales son los de gozar y defender nuestra vida y libertad, de adquirir, poseer y proteger nuestros bienes y reputación y procurar nuestra felicidad. Que todo poder es inherente en el pueblo y todos los Gobiernos libres están fundados en su autoridad e instituidos para su paz, seguridad y felicidad..."51.

Sus ideas liberales y su práctica le sitúan en el esquema propuesto por Joaquín Varela, que distingue liberales de derecha e izquierda según la posición adoptada frente a la Iglesia; la aristocracia; la Monarquía; la democracia y la cuestión social, como un liberal más cercano a la izquierda ${ }^{52}$. En efecto, repudió todo privilegio de la nobleza y propuso organizar la administración con personas de trabajo y de mérito; no defendió el estado laico pero si la tolerancia religiosa permitiendo la educación y algunas prácticas religiosas privadas de los ingleses; repudió la monarquía constitucional optando por el gobierno representativo no heredable; se ocupó en la misma constitución de la situación de las clases menesterosas; aunque alejó a la clases populares del ejercicio del poder político (estableció, como veremos, un senado designado ${ }^{53}$ ); declaró abolidos los títulos de

Cabe recordar, en todo caso, que Bolivar tuvo en algún momento (1823) una pésima imagen de O`Higgins. Como nos recuerda Demetrio Ramos, se refería a él como "un déspota estúpido, aborrecido generalmente por su crueldad y mala administración" y como un césar que no amaba la libertad (en Demetrio Ramos Pérez, "El proyecto de 1826: una clave en la evolución de Bolívar", Cuadernos Hispanoamericanos, núm. 401 noviembre 1983, pp. 21-32, pp. 30 y 32).

48 Véase por todos Alfredo Gómez Alcorta, Francisco Ocaranza y Martín Lara, "Ilustración y modernidad en la figura histórica e intelectual de don Bernardo O`Higgins Riquelme”, páginas 5170, en Epistolario, Tomo I. op. cit. Constituye una adecuada síntesis de los estudios históricos más relevantes sobre el Libertador.

49 Miranda dedicó a O`Higgins el Decálogo "Consejos de un viejo sur-americano a un joven patriota" (Manuel Ortuño Martinez, "Hispanoamericanos en Londres a comienzos del siglo XIX", en revista Espacio, Tiempo y Forma, Serie V.Historia Contemporánea, t 12, 1999, pp., 45-72).

50 Fernando Arrau Corominas, El diputado Bernardo O’Higgins en el Congreso de 1811, Santiago de Chile: Ediciones Biblioteca del Congreso Nacional de Chile, 2009.

51 Carta a José María Benavente de fecha 13 de febrero de 1811, en Epistolario, op. cit., p. 130

52 Joaquín Varela Suanzes-Carpegna, "Retrato de un liberal de izquierda", Historia

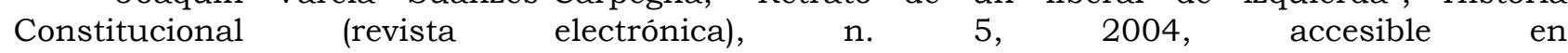
https://dialnet.unirioja.es / ejemplar/94188

53 Volveremos sobre esta temática al analizar la regulación de la ciudadanía, el proceso legislativo y la reforma constitucional. 
Eric Eduardo Palma González

nobleza, prohibió fundar nuevos mayorazgos; y se ocupó de establecer un régimen de educación público.

Si O’Higgins fue un liberal cercano a posiciones de izquierda del liberalismo ${ }^{54}$, sus ideas sobre la participación "popular" lo alejan del republicanismo.

Dijo al respecto el año 1852 el general chileno José María de la Cruz, compañero de armas y leal amigo de O`Higgins, reflexionando sobre:

"Sus principios politicos.

Estos eran republicanos democráticos, pero, no de aquella democracia que pretende someter al común del pueblo el ejercicio de la administración pública.

En medio de esos principios democráticos, creía que ese ejercicio sólo era inherente a la parte del pueblo sensata e independiente para juzgar. Reconocía como necesario restringir o balancear de algún modo la fuerza organizadora de este poder popular, para evitar la anarquía en que se halla propenso a caer por los intereses de partido, y de aquí el que juzgaba necesario la organización de un segundo cuerpo representativo que fuera elegido por un menor número de personas que diesen más seguridad en el acierto de la elección"55.

54 De acuerdo con la distinción que propone Alberto Vivar Flores (2006), entre liberalismo radical, liberalismo moderado y liberalismo doctrinario, O`Higgins sería un liberal moderado con algunos matices que lo acercan a posiciones radicales, en la medida que asume el problema de la pobreza y de la educación pública como uno político: un Estado activo abría la posibilidad de la ciudadanía para los sectores más desposeídos.

Que la clasificación y adscripción es asunto complejo se constata a la luz de la propuesta de entender que hay un "liberalismo democrático preocupado por los problemas sociales" en la medida que interesa la abolición de la esclavitud (véase Marco Jamanca Vega, "El liberalismo peruano y el impacto de las ideas y de los modelos constitucionales a inicios del siglo XIX", en Historia Constitucional (revista electrónica), n. 8, 2007. http://hc.rediris.es/08/index.html

La clasificación del liberalismo de O’Higgins nos conduce al enorme desafio presentado por Roberto Breña el año 2006, de identificar y caracterizar las abundantes maneras que adoptó el liberalismo en Iberoamérica en el primer tercio del siglo XIX. Quién también llama la atención sobre la ambigüedad e indeterminación de este pensamiento. En igual sentido se manifiesta Javier Fernández Sebastián, coord., "En busca de los primeros liberalismos iberoamericanos", en La aurora de la libertad. los primeros liberalismos en el mundo iberoamericano. Marcial Pons, 2012; e Ignacio Fernández Sarasola, "El primer liberalismo en España (1808-1833)", en Historia Contemporánea número 43, 2011, pp., 547-583

55 Miguel Luis Amunategui Reyes, Don Bernardo O`Higgins Juzgado por algunos de sus Contemporáneos, según documentos inéditos, Santiago de Chile. Imprenta Universitaria, 1917, pp. 68 y 69

Bolivar en la Carta de Jamaica (1815) expresaba a este respecto: "En tanto que nuestros compatriotas no adquieran los talentos y las virtudes politicas que distinguen a nuestros hermanos del Norte, los sistemas enteramente populares, lejos de sernos favorables, temo mucho que vengan a ser nuestra ruina. Desgraciadamente, estas cualidades parecen estar muy distantes de nosotros en el grado que se requiere... ¿Se puede concebir que un pueblo recientemente desencadenado, se lance a la esfera de la libertad, sin que, como a İ́caro, se le deshagan las alas, y recaiga en el abismo? Tal prodigio es inconcebible, nunca visto. Por consiguiente, no hay un raciocinio verosímil, que nos halague con esta esperanza" (revisamos el texto en Eduardo Rozo Acuña, Simón Bolivar. Obra política y constitucional, Editorial Tecnos, 2007, Apéndice p. 21) 
O`Higgins escribió sobre esta misma cuestión el 18 de octubre de 1821:

"Si Chile ha de ser República, como lo exigen nuestros juramentos y el voto de la naturaleza indicado en la configuración y riqueza que lo distingue; si nuestros sacrificios no han tenido un objeto insignificante; si los creadores de la revolución se propusieron hacer libre y feliz a su suelo y esto sólo se logra bajo un Gobierno Republicano y no por la variación de dinastías distantes; preciso es que huyamos de aquellos fríos calculadores que apetecen el monarquismo; ¡cual dificil es, mi amigo, desarraigar hábitos envejecidos! Los hombres ilustrados como $\mathrm{V}$, de razón y juicio privilegiados, son los únicos que pueden convencer y persuadir. Ojalá se dedicara algunos ratos a este importante objeto ique de bellezas y reflexiones no ocurrirán a usted sobre la forma de gobierno más conveniente a Chile, para que así se precava el monarquismo europeo, como se ha pensado dividir la América"56.

En agosto de 1822, en medio de sus conflictos con la iglesia y el senado, afirmaba: "lo aprovechan los monarquistas argentinos para desconceptuar nuestro Gobierno, que ha sido el baluarte contra sus maquinaciones que hoy quieren ocultar bajo la hipocresía de liberalismo"57. Calificando las acciones para instalar una monarquía como "vil maniobra" y ataque impune a la inocencia de los pueblos.

$\mathrm{Su}$ opción por el gobierno representativo ${ }^{58}$, no sin algunas resistencias de San Martín, le asegura un lugar destacado en el grupo de los líderes del proceso de independencia, alguno de los cuales, como el propio José de San Martín, Antonio José de Irisarri, Bernardino Rivadavia y Miguel Belgrano, se inclinaban por la fórmula monárquico constitucional.

Por otra parte, su ideario no lo transforma en un creyente en el poder de las ideas para avanzar, sólo por su difusión, hacia la concreción de una organización de libertades y derechos que genere la felicidad del pueblo59. Identifica lo que llama limitaciones de la sociedad chilena para implementar cabalmente la fórmula gubernamental representativa, y una organización liberal de libertades y derechos que genere la felicidad del pueblo:

56 Epistolario, Tomo I., op. cit., p. 291. Ideas que reitera en carta de 24 de octubre de 1821 dirigida a José Rivadeneira y Texada ((Epistolario, Tomo I., op. cit,, p. 192) y que precisa el 16 de marzo de 1822 en carta dirigida a José de Irisarri en el sentido que la monarquía sólo se pensó en algún momento "si la revolución sufriese contrastes que amenazasen ruina" y que para adoptar una decisión se debía tener claridad sobre las formas de gobierno adoptadas por México, Colombia, Perú y las Provincias del Río de la Plata, lo que "dista mucho del proyecto que había sugerido la cobardia y que tanto detestan los pueblos" (Epistolario, Tomo I., op. cit,, pág. 305).

57 Epistolario, Tomo I., op. cit., pág. 323

58 No es este el espacio para avanzar en este concepto, sin embargo, cabe precisar que la voz gobierno representativo es vez de régimen republicano o república, parece ser una noción más pertinente para describir la disyuntiva que normalmente se presenta como Monarquía/República en la explicación sobre la independencia (véase Alejandro San Francisco y Cristina Moyano, "E1 liberalismo en Chile en el siglo XIX. La formación del concepto, su trayectoria y sus dimensiones", en Javier Fernández Sebastián (coord.), La aurora de la libertad, op. cit.

59 O’Higgins está cercano en esta materia a las ideas de Bolivar que desconfiaba de la "ciencia libresca y el poder de las ideas revolucionarias francesas" y recomendaba atender al carácter y circunstancias del pueblo (véase con provecho para este punto de André Pons "Bolívar y Blanco White", Anuario de Estudios Americanos, tomo LV, 2, 1998, pp. 507-529 
"Según mi propia convicción me parece indudable que el primer Congreso de Chile va a dar muestras de la más pueril ignorancia y a hacerse reo de toda clase de insensateces. Tales consecuencias son inevitables en nuestra situación actual, careciendo, como carecemos, de toda clase de conocimientos y experiencias. Pero es preciso comenzar alguna vez, y mientras más pronto sea, mayores ventajas obtendremos"60.

Asimismo, surgió en él la conciencia de ocuparse de las condiciones materiales y espirituales en que se desenvuelve el bajo pueblo, actor relevante en la guerra de independencia. Reflexiona al respecto:

"El riesgo no puede ser mayor: él amenaza la existencia individual: y cuando la clase última de la sociedad, los hombres más indigentes que nada tienen que esperar ni que perder, son llevados por el brazo fuerte del Gobierno a sacrificar su vida, único bien de esos infelices, por la conservación de las otras clases que disfrutan de todos los beneficios sociales, no es sufrible que miremos con indolencia perderse la República por respetar una parte de la fortuna de los Ciudadanos. El Gobierno que dispone de la sangre y de la vida de cientos de hombres en los momentos del peligro, que no pueda a la par hacer uso de una corta porción de los bienes, o más bien de lo más superfluo de los otros para el mismo sagrado objeto, parece una paradoja. Hágase de una vez un sacrificio grande; dese [sic] un empuje decisivo para concluir la guerra, cimentar la paz y asegurar sólidamente nuestra existencia común o individual. Lo exige así la política, la conveniencia y todos los principios razonables" 61 .

Ya tendremos ocasión de ver que estas ideas tendrán alguna influencia en el diseño constitucional.

Como ya hemos visto, la opción por el gobierno organizado a la manera representativa, no impide que buena parte de la historiografia constitucional califique a su gobierno como un régimen dictatorial. Un grupo menor de autores se inclina por llamarlo autoritario ${ }^{62}$.

\section{EL IDEARIO CONSTITUCIONAL DE O`HIGGINS}

En el Manifiesto por el cual se justifica la independencia, O`Higgins reflexiona respecto de la Constitución:

"se promulgan esos altos derechos del hombre, los principios sagrados del pacto social, las prerrogativas de los pueblos y la retroversión a éstos del

60 Carta al coronel don Juan Mackenna, en Epistolario, op. cit., p.129

Ideas semejantes se encuentran en su asesor y redactor del diario El Censor de la Revolución, publicado en Santiago de Chile en 1818, Bernardo Monteagudo según da noticia Gustavo Montoya, "Pensamiento político de Bernardo Monteagudo. Entre el autoritarismo y la democracia”, en Investigaciones Sociales, año V, núm. 8, pp 81-111, Lima, 2001.

61 Carta de Bernardo O`Higgins a Zenteno, 10 de septiembre de 1821, en Archivo Nacional Ministerio de Guerra, vol. 73, carta $\mathrm{N}^{\circ} 68$, s.f., citada por; Leonardo León, Ni patriotas ni realistas. El bajo pueblo durante la Independencia de Chile, 1810-1822. Ediciones de la Dirección de Bibliotecas, Archivos y Museos, 2011, p. 800

62 Julio Heise, Años de formación y aprendizajes políticos 1810-1833, Editorial Universitaria, 1978. La misma idea en Alfredo Gómez Alcorta, Francisco Ocaranza y Martín Lara, Ilustración y modernidad, op. cit. 
ejercicio de la soberanía que antes se desempeñaba por el Rey como un apoderado suyo, imposibilitado ya de administrarla en el cautiverio; se nos promete, en fin, la gloriosa perspectiva de una Constitución que, refrenando la arbitrariedad del gobierno, sea el antemural de la libertad del ciudadano llamado a darse a sí mismo la ley por medio de sus representantes en un Congreso Nacional"63.

El preámbulo de ambas cartas constitucionales y los documentos que generó O`Higgins a propósito de su gestación, constituyen una fuente privilegiada para comprender la visión del Director Supremo sobre la constitución y la cultura constitucional ${ }^{64}$.

Al respecto en mayo de 1818 señalaba:

"Hallándose el Estado, por las circunstancias dificiles en que se ha visto hasta hoy, sin una Constitución que arregle los diversos poderes, señale los límites de cada autoridad, y establezca de un modo sólido los derechos de los ciudadanos, a pesar de habérseme entregado el gobierno supremo sin exigir de mi parte otra cosa que obrar según me dictase la prudencia, no quiero exponer por más tiempo el desempeño de tan arduos negocios al alcance de mi juicio. Si me fue lisonjera la absoluta confianza de mis conciudadanos, no me fue menos penosa la necesidad de admitirla, porque mis sacrificios por la Patria solo tuvieron por objeto la salud pública, y no puede dejarme satisfecho el temor de hacer inútiles mis trabajosas tareas. Hasta este dia, las atenciones de la guerra han llamado hacia ella todos mis conatos, porque sin vencer a un enemigo que nos venía a destruir con fuerzas superiores, hubiera sido un delirio pensar en otra cosa, y mucho más en negocios tan graves, que solo pueden evacuarse en medio de la serenidad de la paz. Pero ya que por el valor y la virtud de nuestros soldados, hemos conseguido vencer y destruir a los tiranos, solo me ocupo en preparar aquellas medidas que aseguren la libertad de los chilenos, sin introducir la licencia, en que escollaron otros Estados nacientes" 65 .

En carta dirigida al general Juan Salazar, Ministro de Estado en las carteras de Guerra y Marina del Perú, fechada el 8 de mayo de 1828, O`Higgins presentó su acabada visión acerca de la Constitución:

"Interesado siempre en la felicidad de la República peruana (mi patria adoptiva), he leído con el gozo más satisfactorio la Constitución Política que el Congreso Constituyente ha dado a los pueblos que legítimamente representa. Séame permitido, señor Ministro, expresar que este venerable

63 Manifiesto que hace a las naciones el Director Supremo de Chile de los motivos que justifican su revolución y la declaración de su independencia, versión en línea en https://www.leychile.cl/Navegar?idNorma=1063810 (Biblioteca del Congreso Nacional)

64 Casimiro Albano menciona en su obra, una constitución redactada por O`Higgins, a partir de la experiencia vivida en Hispanoamérica, y que fue concebida como modelo para nuestras republicas, sin embargo estar en su poder, no la da a conocer por habérselo pedido el mismo O`Higgins. Lamentablemente no he podido dar con este texto.

65 Sesiones de los Cuerpos Legislativos de la República de Chile/1818/Origen Histórico del Senado de 1818, versión en línea https://es.wikisource.org/wiki/Sesiones_de_los_Cuerpos_Lejislativos_de_la_Rep\%C3\%BAblica_de _Chile/1818/Or\%C3\%ADjen_Hist\%C3\%B3rico_del_Senado_de_1818 
instrumento tan justamente deseado y que ahora se presenta a la vista de los hombres libres y a la del cielo, señalando los poderes y prescribiendo los deberes del magistrado, como los del ciudadano, es la columna más fuerte para detener a los enemigos de la obediencia y el orden, y para que el ciudadano ame y defienda con valor una forma de gobierno que, al mismo tiempo que afianza el derecho individual, forma la más perfecta unión, establece la justicia, asegura la tranquilidad doméstica, provee a la dicha común, promueve el bienestar de una patria tan querida y asegura la libertad y la felicidad de la asociación nacional en una extensión más allá de la suerte ordinaria de la humanidad. Pasados los siglos de opresión, el espíritu humano se deshace por su libertad ¡Venturoso Perú, que en la carta sagrada que recibe por herencia de aquellos a quien debe su establecimiento, divisa acercarse completa la estructura de la sociedad civil por los irresistibles progresos de la ilustración y de la opinión! ¡Quiera el cielo que la adopción de este pacto social formado por ilustres y eminentes Padres de la Patria y como el fruto de inmensos sacrificios, sea transmitida sin merma a las generaciones futuras y que los rayos de su luz iluminen a otros países de Sudamérica!66

En síntesis, podemos afirmar que O’Higgins sostiene en su discurso público y privado la soberanía del pueblo; el ejercicio de la soberanía por el pueblo de Chile como pueblo libre; reconoce el derecho del pueblo de Chile a darse la forma de Gobierno que estime adecuada ${ }^{67}$; fomenta el respeto a la Constitución por las autoridades; reconoce la existencia de derechos individuales como derechos del género humano68; condena la monarquía absoluta como forma de Gobierno opresiva de los derechos y libertades del individuo; concibe la constitución como instrumento para la protección y promoción de las libertades individuales, inclusive la libertad de conciencia; reconoce y promueve la igualdad ante la ley ${ }^{69}$; la propiedad y el buen nombre; se ocupa de las clases menesterosas; acepta el principio de división de los poderes como estructura de organización del poder público; establece la felicidad del pueblo como objetivo central de la actividad del

66 Epistolario de don Bernardo O`Higgins. Tomo II. editores Alfredo Gómez Alcorta, Francisco Ocaranza, ediciones Universidad Bernardo O`Higgins, Santiago de Chile, 2011, p. 463.

67 Afirmó en el preámbulo de la Constitución Provisoria de 1818: “... nombré una comisión, compuesta de los sujetos más acreditados por su literatura y patriotismo, para que me presentasen un proyecto de Constitución provisoria, que rigiese hasta la reunión del Congreso Nacional. Yo hubiera celebrado con el mayor regocijo, el poder convocar a aquel cuerpo constituyente, en vez de dar la comisión referida; pero no permitiéndolo las circunstancias actuales, me vi precisado a conformarme con hacer el bien posible".

68 El 1 de abril de 1817 escribe al Presidente de los Estados Unidos dando a conocer la victoria sobre las tropas españolas. Señala entonces: "Reasumidos los derechos que concede al hombre la naturaleza, no sufrirán en los sucesivo los habitantes de Chile el despojo de sus prerrogativas naturales ni la mezquindad de la política ominosa del gabinete español” (Epistolario, Tomo I., op. cit., p. 158)

69 En carta a Juan Florencio Terrada de fecha 20 de febrero de 1812 señala: "Detesto por naturaleza la aristocracia, y la adorada igualdad es mi ídolo. Mil vidas que tuviera me fueran pocas para sacrificarlas por la libertad e independencia de nuestro suelo y tengo el consuelo de decir que la mayor parte de los descendientes de Arauco obran por los mismos principios" (Epistolario, Tomo I., op. cit., p. 132). Distingue O`Higgins claramente en diversas cartas la libertad civil de la política (Epistolario de don Bernardo O`Higgins. Tomo I., op. cit., pp. 161, 193, 194). 
gobernante; y considera de suma relevancia la instrucción del pueblo y la libertad de opinión y de prensa, con las limitaciones debidas en aras del orden y la religión ${ }^{70}$.

Estas ideas tendrán como escenario para desplegarse la guerra de independencia, así como los conflictos políticos de los grupos dirigentes, lo que las debilitará generando una práctica política que las cuestiona en algunos de sus aspectos. En un primer momento el poder total le es entregado a O’Higgins por la elite santiaguina, que solicita al Director obrar como dictador, pero, eliminada la amenaza española, las acciones de su Gobierno y la reacción del patriciado y los exaltados ante las mismas, generarán, entre otros fenómenos dialécticos, las constituciones de 1818 y 1822 . La inexistencia de un mecanismo constitucional que hiciera efectiva su propia responsabilidad política o jurídica, se convirtió en el principal argumento de sus contradictores para descalificar su obra politica y constitucional.

\section{LA PRÁCTICA CONSTITUCIONAL DEL DIRECTOR SUPREMO: REGULACIONES DE LA CARTA CONSTITUCIONAL DE 1818 Y COMPARACIÓN CON LAS CARTAS CHILENAS DE 1812 Y 1822}

El 17 de abril de 1818 el cabildo de Santiago, que meses antes había dejado en manos de San Martín y O`Higgins la decisión de gobernar como dictadores, exigió al Director Supremo el nombramiento de una comisión redactora de un reglamento constitucional. El 18 de mayo de 1818 O'Higgins nombró una comisión. Terminado su trabajo en el mes de agosto, propuso al Gobierno que la constitución "fuera aprobada por cabildos, otras corporaciones, funcionarios civiles, miembros del clero y oficiales del ejército"71.O'Higgins optó por una consulta popular, tal como ocurrió con la declaración de independencia. Usó el sistema de los dos libros. Encargó a las parroquias (cura, juez, escribano) recoger los votos. Declaró hábiles para suscribir "a todos los habitantes que sean padres de familia, o que tengan algún capital, o que ejerzan algún oficio, y que no se hallen con causa pendiente de infidencia o de sedición. Serán inhábiles todos aquellos que procuren seducir a otros, haciendo partidos, o tratando de violentar o de dividir la voluntad de otros"72.

Dado que promulgó dos textos constitucionales, para comprender mejor el alcance del texto de 1818, objeto central de este artículo, y su lugar en la historia constitucional chilena, resulta pertinente comentar los alcances del texto bicentenario a la luz de la carta de 1822, y en algunos casos de la regulación precedente de 1812. Utilizaremos para ello, un conjunto de categorias de análisis que ya empleamos en el estudio de la totalidad de las constituciones chilenas del periodo 1812-1833.

70 Luis Valencia Aravia, en "Apuntes sobre la politica constitucional de O’Higgins”, op., cit., no aborda estas materias, limitándose a comentar el texto Plan de Hacienda y Administración Pública, al que caracteriza como texto constitucional con vigencia de unos dias y sepultado por la guerra. En 1974 publica una recopilación de escritos del prócer (El Pensamiento de O’Higgins. La Pluma y Espada, Editorial del Pacífico, Santiago, 1974). En 1978, según veremos, hizó una breve descripción de los textos de 1818 y 1822.

71 Luis Galdames, La evolución constitucional... op. cit., p. 486

72 Luis Galdames, La evolución constitucional... op. cit., p. 488 


\section{Evaluación del texto siglo XIX y XX}

Casimiro Albano sostuvo en 1844 una visión favorable al texto como señal de sujeción de O`Higgins al derecho.

Amunateguí contrasta Monarquía, dictadura y república, siendo característica de esta última estar "basadas en la soberanía popular, y en las cuales los cargos públicos son electivos y alternativos" y todos los hombres se conciben como iguales. Por ello, afirma, ni Bolivar, que propuso la presidencia vitalicia, ni San Martín que promovia la Monarquía constitucional, "eran republicanos"73. Ambos no percibieron, dice Amunategui en 1853, que "en América las dictaduras, las presidencias vitalicias son imposibles. Los semidioses no son de este tiempo"74, ni que en la alternancia en el poder propia de la república estaba el factor de estabilidad del estado: los derrotados en las elecciones contaban con la alternancia y por ende repudiaban la violencia política. Solo "necesitan para eso una constitución que asegure las garantías y derechos de todos"75.

Lastarria afirma que O' Higgins se inspiró en la conducta de Napoleón: "Lo que había sancionado el pueblo por sus firmas era la constitución de un poder absoluto unipersonal, tan ilimitado como el de los antiguos presidentes de la colonia, y tanto más terrible cuanto que la latitud de sus facultades y su irresponsabilidad estaban excusadas por una Constitución aprobada por el pueblo"76.

Juicio semejante al de Amunategui, quién luego de describir los poderes con que la Constitución dotaba al Director Supremo, afirmó:

"Todas estas medidas dejaban constituidas en Chile la dictadura más absoluta, disfrazada bajo ciertas apariencias hipócritas, que sólo podian engañar a los muy inocentes, o a los que querian dejarse alucinar. La Constitución que se otorgaba como una concesión a las exigencias de la opinión pública, no era, poco más o menos, sino la redacción en el papel de cuanto se había estado practicando desde la victoria de Chacabuco. O’Higgins, en realidad, después de la promulgación de la carta fundamental, quedaba con facultades tan omnimodas, como las que tenía antes de que se hubiera dictado"77.

Orrego Vicuña juzgaba en 1924 que:

"Hija de su tiempo y de las condiciones dificiles y premiosas en que fue dictada, la Constitución de 1818 no podía ser, a nuestro juicio, un modelo acabado de código fundamental. Como el Director Supremo juzgaba muy bien, el país no estaba aún preparado, ni la (sic) estaría en mucho tiempo, para un régimen de grandes libertades, Una nación que, como Chile, recién

73 Miguel Luis Amunategui, La Dictadura, op. cit., pp. 11 y 13

74 Miguel Luis Amunategui, La Dictadura, op. cit., p. 16

75 Miguel Luis Amunategui, La Dictadura, op. cit., p. 24

76 José Victorino Lastarria, "Historia Constitucional del Medio Siglo", en José Victorino Lastarria, Obras Completas, Volumen VII, Santiago de Chile, 1909, p. 332

77 Miguel Luis Amunategui, La Dictadura, op. cit., p, 257 
sacudía el yugo de una larga opresión, extendida en el curso de varios siglos de esclavitud y coloniaje, no podía entrar de lleno y repentinamente a gozar de todas las libertades, de que por espacio tan largo había carecido"78.

Evaluando el texto de 1818 señaló Galdames en 1925:

"Antes que una consagración de garantías ciudadanas, significaba un instrumento de gobierno, una manera de disfrazar la autoridad de hecho en ejercicio, con la máscara de un derecho que en el fondo era igual, aunque el vulgo pudiera engañarse... el régimen que emanaba de la constitución de 1818, parecia remedar el implantado por aquel espíritu dominador del Consulado francés de 1799. La misma concentración de autoridad en una sola persona, la misma ineficacia de control por parte de otro poder cualquiera, el mismo desprecio u olvido de la potestad legislativa y aún de las libertades públicas, el mismo propósito de prevenir aún la más leve conmoción interna, y hasta la misma fórmula para reconocer sin compromiso la soberanía popular, en una consulta plebiscitaria... La constitución de 1818 no tenía nada de monárquico, pero tampoco era republicana, sino dictatorial... ${ }^{79}$.

Califica de muy avanzada para la época la consagración de deberes sociales del Estado.

En relación con la protección de la Constitución y las garantías individuales comenta: "El poder ejecutivo y algunos de sus agentes, no respetaron con estricto rigor las garantías individuales. En cumplimiento de sus deberes, el senado se lo representó más de una vez al jefe supremo y sostuvo tenaz lucha para impedir esta clase de transgresiones. De igual modo, hubo de salir en defensa de la autonomía del poder judicial... Observó hasta los decretos sin firma"80.

El Senado exigió a O’Higgins que se procediera a la elección de intendentes y teniente gobernador como lo ordenaba la Constitución, pero no fue oído.

O’Higgins por su parte convocó a elecciones del Congreso, facultad que el Senado entendia le era privativa.

Finalmente y luego de un cúmulo de desavenencias el Director Supremo suspendió indefinidamente las sesiones del Senado.

El 23 de julio de 1822 se eligió Congreso en una elección que Galdames califica de intervenida escandalosamente. Se reunieron 30 diputados. O'Higgins la consideró una reunión respetable dada las condiciones del país y dejó para una mejor época una organización en forma.

Un balance semejante se encuentra en Eyzaguirre (1955) que califica el gobierno de O`Higgins como una dictadura que se vio obligada, por la presión de la diplomacia norteamericana y nacional, luego del fusilamiento de los hermanos Carrera (sus enconados opositores), a promulgar una constitución, la Constitución de 1818.

\footnotetext{
78 Luis Orrego Vicuña, El espíritu constitucional, op. cit., pág. 54

79 Luis Galdames, La evolución constitucional... op. cit., pp., 502. 504 y 505

80 Luis Galdames, La evolución constitucional... op. cit., p. 527
} 
El autor referido analiza la Constitución en un par de páginas y concluye que el Senado que ella estableció, aunque designado, limitó las prerrogativas del Director Supremo:

"Aunque la Constitución de 1818 no tenía más objetivo que reforzar legalmente los poderes omnimodos del Director, el Senado brotado de sus manos tuvo independencia suficiente como para resistir con energias las demasias de su voluntad. Una larga polémica se entabló entre ambas potestades, hasta que O`Higgins el 7 de mayo de 1822, dio término a la existencia del Senado convocando a elecciones para una asamblea"81 .

El congreso de 1822, en cuya elección intervino O`Higgins de forma abierta, fue convocado para proponer las bases de la convocatoria de un congreso constituyente, pero, terminó discutiendo y aprobando, no sin resistencia, la Constitución de $1822^{82}$.

En 1978, Julio Heise, distanciándose de estas perspectivas sostendrá que: "Al iniciarse el movimiento emancipador, O`Higgins era partidario entusiasta de la más amplia democracia y del ejercicio, sin limitación alguna de todas las garantías constitucionales.... -pero- se dio cuenta que el ejercicio pleno del liberalismo era imposible: faltaban la tradición y la cultura cívicas. Sólo cabía organizar un autoritarismo legal dentro de un marco democrático mientras se lograba cierta madurez politica"83. Concluye Heise que repudiaba la monarquía así como la dictadura, y consideraba necesario para el funcionamiento de la república un gobierno fuerte y autoritario.

El mismo autor firma que en Chile, al contrario del resto de América, la lucha por la independencia y la organización del Estado se vivió en una sola etapa y que en ello tuvo una gran responsabilidad el prócer: "En Chile fue, sin duda, la firme y clara conciencia democrática y republicana de O`Higgins, la que hizo posible que la guerra de la Independencia se desarrollara en un marco de vida civica perfectamente regular"84. Concluirá que el Director Supremo no fue un dictador sino que configuró un "autoritarismo legal".

Es claro que ambas cartas fundamentales no fueron expresión de la voluntad nacional recogida mediante un mecanismo representativo, que la interpretara de manera más o menos cabal, sin embargo, De la Cruz atribuye a O`Higgins la siguiente reflexión: "Es cierto que la formación de la constitución no

81 Jaime Eyzaguirre, Historia Constitucional de Chile. Apuntes de clase, Editorial Universitaria, Santiago, 1955, p. 65

Fernando Campos Harriet, en Historia Constitucional de Chile, editorial Universitaria, Santiago de Chile, 1956, p. 437 señala: "Es necesario convenir que O’Higgins, en general, respetó al Senado y a los Tribunales".

82 Sergio Carrasco Delgado, en "Estudio histórico y jurídico acerca de la génesis de los distintos textos constitucionales chilenos", Revista de Derecho, núm. 165, año XLIV (ene- dic. 1977), Universidad de Concepción, pp. 49-73, da cuenta de este sustantivo debate que terminó teniendo relevancia al afectar la vigencia

83 Julio Heise, "O`Higgins y la organización de la República", en Revista Chilena de Historia y Geografia, número 146, 1978, p. 81

84 Julio Heise, O`Higgins forjador, op. cit., p. 16

Heise afirma que la falta de rigor de los historiadores para abordar la odiosidad de los enemigos del prócer, permitió el surgimiento de la leyenda negra y el mito de la dictadura. 
es enteramente legal, pero lo es sí, más, que la que regía del año 18, y se hallan mejor y más extensamente designadas las garantias individuales" 85 .

\section{Análisis de la normativa constitucional de $1818^{86}$}

Se trata de una constitución conformada por cinco títulos, quince capítulos y 143 artículos. Los títulos abordan los derechos y deberes del hombre en sociedad; la religión oficial del Estado; de la potestad legislativa; del poder ejecutivo y de la autoridad judicial.

\subsection{Dios y orden constitucional, constitución con religión oficial}

La carta constitucional es manifestación del Estado constitucional liberal católico 87 , tal como el Reglamento Constitucional Provisorio de 1812 y la Constitución de 1822.

Las tres constituciones protegen la religión y consagran como oficial a la católica. En la Constitución Provisoria de 1818 se invoca a Dios como fuente adicional de legitimidad del orden constitucional (el preámbulo señala "en nombre de Dios omnipotente, creador y supremo legislador"88); se establece la religión católica como oficial; se limita la libertad civil en materia religiosa ("ninguno se le puede privar de la libertad civil, que consiste en hacer todo lo que no daña a la religión..."); se limita la libertad de expresión ("Todo hombre tiene libertad para publicar sus ideas y examinar los objetos que están a su alcance, con tal que no ofenda la...conservación de la religión cristiana, pureza de su moral y sagrados dogmas"); se exige al buen patriota cumplir los deberes para con la religión ("Todo individuo que se glorie de verdadero patriota, debe llenar las obligaciones que tiene para con Dios..."); y se consagra la religión oficial ${ }^{89}$.

La Carta de 1822 avanzó en una mejor determinación de los alcances de los deberes de los individuos para con Dios y de la consagración de la religión oficial,

85 Miguel Luis Amunategui Reyes, Don Bernardo O`Higgins...op. cit., p. 86

86 No seguimos la propuesta de análisis de Fernando Martínez L, "La Constitución Política del año 1818", Revista Universidad de Chile, N 4, Universidad de Chile, Sede Ñuble, 1978, pp. 18-23, quien se limita a realizar un análisis puramente exegético del texto.

87 Para una explicación del alcance de este fenómeno, véase de Eric Eduardo Palma G, Estado constitucional Liberal Católico en Chile (1812-1924), op. cit.

88 El juramento de obediencia a la constitución dispone. "y se jurará en la forma siguiente: Juro por Dios Nuestro Señor, y estos Santos Evangelios, que cumpliré y observaré fiel y legalmente en la parte que me toca, todo cuanto se contiene y ordena en esta Constitución provisoria. Si así lo hiciere, Dios me ayude, y si no, El y la Patria me hagan cargo". En términos semejantes se reguló en la Constitución de 1822.

89 “Título II. De la religión del Estado. capitulo único. La religión Católica, Apostólica, Romana es la única y exclusiva del Estado de Chile. Su protección, conservación, pureza e inviolabilidad, será uno de los primeros deberes de los jefes de la sociedad, que no permitirán jamás otro culto público ni doctrina contraria a la de Jesucristo".

Orrego Vicuña sostuvo en 1957 que O`Higgins era partidario de la tolerancia religiosa y por ende de la libertad de culto, posición liberal, pero la Comisión que preparó el texto de 1818 no accedió a esta regulación. 
haciendo responsable también a los particulares de su cuidado y llevando las manifestaciones de disidencia a la esfera privada ${ }^{90}$.

Todo lo cual no fue obstáculo para prohibir la actuación en Chile del tribunal de la Inquisición (primero a nivel legal y luego constitucional ${ }^{91}$ ).

\subsection{Responsabilidad por infracción de la Constitución y visión de la misma como norma juridica vinculante}

La carta de 1818 posee mecanismo de responsabilidad por infracción de constitución. Se señaló en el Capítulo III del Título Primero artículos 1 al 3, que correspondía al Senado como atribución esencial "celar la puntual observancia de la Constitución". De la infracción cometida por algún cuerpo o ciudadano debía informarse al Director Supremo, "quien deberá atenderla bajo su responsabilidad".

Se estableció la figura del censor, ente presente en todas las ciudades y villas, elegido por el cabildo, y a quien se le encargó cuidar de "la observancia de esta Constitución... y en las trasgresiones que notare, así en los funcionarios del pueblo como del campo, oficiará por primera y segunda vez al Gobernador o Teniente, para remedio, y en caso que éstos no lo hagan eficazmente, dará parte al Senado" $"$.

Cabe reparar en que la tutela de la normativa constitucional recae, como en la Carta de Cádiz de 1812, en un órgano político como es el senado y no en un ente judicial.

Respecto de los "Secretarios del Poder Ejecutivo" (ministros de Estado) el Capítulo III, del Título IV señala en el artículo 3: "Ninguno de los secretarios

90 "Artículo 9.- Todo chileno debe llenar las obligaciones que tiene para con Dios y los hombres, siendo virtuoso, honrado, benéfico, buen padre de familia, buen hijo, buen amigo, buen soldado, obediente a la Constitución y a la ley, y funcionario fiel, desinteresado y celoso.

Título II De la religión de Estado Capítulo único. Artículo 10.- La religión del Estado es la Católica, Apostólica, Romana, con exclusión de cualquiera otra. Su protección, conservación, pureza e inviolabilidad es uno de los primeros deberes de los jefes del Estado, como el de los habitantes del territorio su mayor respeto y veneración, cualquiera que sean sus opiniones privadas.

Artículo 11.- Toda violación del Artículo anterior será un delito contra las leyes fundamentales del país.

91 Constitución de 1822, artículo 229: "En ningún caso, ni por circunstancias sean cuales fueren, se establecerán en Chile las instituciones inquisitoriales".

La literatura chilena sostiene una gran influencia de la Constitución de Cádiz en este texto de 1822, sin embargo, mientras en Cádiz se obligó el constituyente a proteger la religión por leyes sabias y justas, en Chile se decidió la prohibición expresa (véase por todos, Javier Barrientos, "La constitución de Cádiz en Chile", en José Antonio Escudero (coord.), Cortes y Constitución de Cádiz, v.3. Espasa Libros. Fundación Rafael del Pino, Madrid, 2011, pp. 674-699; y Juan Luis Ossa Santa Cruz, Revolución y constitucionalismo en Chile, 1808-1814, Revista de Historia Iberoamericana, volumen 5, $\mathrm{N}^{\circ}$ 1, 2012, pp., 111-139); Francisco Zúñiga Urbina, "Constitución de 1812 y su influencia en el constitucionalismo liberal chileno", en Revista española de la función consultiva, núm. 19, 2013, pp. 677-726

92 Según se da cuenta en Valentín Letelier, Sesiones de los Cuerpos Legislativos de Chile, Tomo II (1818-1819), en noviembre de 1818 se eligió el censor de la ciudad de Valparaíso y de la Ligua. 
podrá autorizar ordenes, decretos o providencias, contrarios a esta Constitución provisoria, so cargo de infidelidad al Estado y responsabilidad".

Dicha disposición es muy relevante pues presenta la posibilidad de la inconstitucionalidad de la actividad normativa (reglamentaria) y establece responsabilidad en dicho evento.

La Carta de 1822 dispuso expresamente (artículos 243 y 244) que todo chileno podía pedir que se respetara la constitución y se sancionara a cualquiera que la violara, incluso las máximas autoridades. La normativa perfeccionaba el mecanismo de responsabilidad que en el texto de 1818 sólo tenía como legitimado activo al censor que velaba por la conducta de los funcionarios públicos, estableciendo una acción popular dirigida incluso contra el Director Supremo (este alcance pudo ser objeto de debate interpretativo porque la carta estableció que el Director era inviolable, sin embargo, la práctica implicó que luego de la abdicación se residencia a O’Higgins quién no se refugió en esta norma).

El artículo 244 avanzó además en considerar la infracción como un delito "de los de mayor gravedad", agregando el 245 una sanción de corte político al privar al infractor de sus "derechos de ciudadano por diez años, sin perjuicio de las demás penas que señale la ley".

Cabe recordar que la normativa constitucional chilena de 1812 disponía en su artículo XIII que las autoridades debian jurar solemnemente la observancia del Reglamento Constitucional, “... y en el caso de contravención después de prestado el juramento, se impondrán á los transgresores las penas de reos de alta traición".

La comparación favorece la idea según la cual el ejercicio del poder a la "manera dictatorial" no implicó debilitar la capacidad normativa de la constitución, ni la responsabilidad por su infracción. Sea por voluntad propia o por el accionar de la elite, el Director Supremo perfeccionó el sistema de protección del orden constitucional y facilitó los medios para velar por su aplicación, elevando su violación a la categoría jurídica de delito de alta gravedad (como el de traición según se estableció en 1812).

En la década que va de 1812 a 1822 , se produjo un notable mejoramiento de la técnica legislativa en la formulación de la regla de responsabilidad, así como en el contenido normativo de la misma. Es innegable que la dirigencia política (incluido el propio O`Higgins) entendia que la carta de 1822 se promulgaba para una época muy distinta, en que dictadores y caudillos dan paso a un entramado jurídico político de responsabilidad por infracción de Constitución. De hecho, la Constitución de 1828 llevó la fórmula a su máximo resplandor al permitir la acusación constitucional contra el Presidente de la República por infracción de la Constitución.

De la regulación de 1822 cabe concluir que se había logrado una mejor comprensión del valor del respeto del texto constitucional por las autoridades. Y que los actores políticos estaban dispuestos a controlar el ejercicio del poder, por ello, la regla de la inviolabilidad del Director Supremo debió generar disonancia politica. Es cierto que se habían mejorado los mecanismos de responsabilidad por infracción de constitución de los asesores directos del Director, sin embargo, él se erigió como inviolable. Que lo fuera no significaba que careciera de limites 
institucionales en su gestión y respecto de los politicos, el Senado de 1818 había dado muestras del valor de la acción política de control.

Tratar a la norma constitucional como regla jurídica aplicable, no sólo tiene que ver con que existan mecanismos de responsabilidad por su infracción, sino, que las normas se apliquen o se invoquen en la cotidianidad. Es decir, que exista conciencia de que se trata de un cuerpo normativo aplicable y al mismo tiempo que haya ánimo de aplicar sus mandatos.

A vía de ejemplo, que son necesarios de presentar en atención a la tesis de Bernardino Bravo relativa a las "constituciones de papel"93, cabe señalar, y sin pretender agotar los casos en que se aplicó la Constitución de $1818^{94}$, que ya el 27 de octubre de 1818 el Senado (designado por el mismo director supremo) invocando el art. 18 del cap. 1, tít. IV de la Constitución, solicitó que los Ministros le dieran noticia detallada de los ingresos, gastos y existencia del Tesoro Público95; el 30 de octubre en virtud a lo dispuesto en el art. $5^{\circ}$, cap. II, tít. III de la Constitución provisoria, sobre cómo juzgar las causas que tengan o tuvieren los senadores durante sus empleos, el Senado designó la comisión respectiva96; el 31 de octubre de 1818 el Director Supremo, solicitó al senado la interpretación del art. 11, cap. I, tít. IV de la Constitución del Estado, relativo a la provisión de empleos públicos y la aplicación de la regla tratándose de los empleos militares ${ }^{97}$; el 5 de noviembre de 1818 resolvió el Senado, por razonamiento analógico, que dado que se prohíbe al Senado por mandato del art. $3^{\circ}$, cap. I, tít. III, gozar de dos sueldos, dicha prohibición debe afectar a todos los empleados públicos de cualquier clase o condición ${ }^{98}$; el 13 de noviembre de 1818 se acordó "nombrar al senador don Francisco Antonio Pérez, a don Lorenzo José de Villalón, y a don Ignacio Godoy, miembros de la Cámara de Justicia, para que en conformidad al art. $9^{\circ}$, cap. III, tít. III de la Constitución, residencien a los empleados suspensos o cesantes"99; O’Higgins invocó las normas constitucionales para resolver el nombramiento de Lord Cochrane como almirante de la Armada chilena y para decidir qué Ordenanza de Marina aplicar en los navíos del Estado de Chile ${ }^{100}$; el 19 de marzo de 1819 comunicó a San Martín una importante cuestión relativa a al ejército de los Andes, en el sentido que no podía asegurar el pronto regreso del mismo a Buenos Aires dado que "por la Constitución depende

93 También contrapone el autor la constitución histórica a la escrita, caracterizando a esta última como no aplicada (véase Bernardino Bravo, El Estado en Iberoamérica, op., cit. pp. 191335

${ }^{94}$ Los casos señalados incrementan los identificados por Horacio Aranguiz, en "La aplicación de la Constitución de 1818", en Jaime Eyzaguirre, Fernando Silva, Carlos Ugarte, Estudios de Historia de las Instituciones Políticas y Sociales, Editorial Jurídica de Chile, 1966. Aranguiz se propuso en dicho trabajo dar noticia de la "forma en que fueron complementadas e interpretadas en la práctica las disposiciones" de la carta de 1818 (p. 123).

95 Valentín Letelier, Sesiones de los Cuerpos Legislativos de Chile, Tomo II (1818-1819), op. cit

96 Ibid

97 Ibid

98 Ibid

99 Ibid

100 Archivo de don Bernardo O’Higgins, Tomo XXXV. ... op. cit., véase p. 21 y p. 7 -"Como en el art. $4^{\circ}$. cap. $2^{\circ}$ tít. $4^{\circ}$ de la Constitución chilena prohíbe el dar empleo alguno, sino a los que son ciudadanos chilenos, para salvar este inconveniente en la provisión del empleo de Almirante..."- 
del Senado" y debe esperarse su resolución ${ }^{101}$; en este mismo mes de marzo de 1819, el ciudadano Tomás de Garmendia presentó ante el Director Supremo reclamo por las arbitrariedades de su arresto por parte del Teniente de Gobernador, afirmando "si somos castigados y sacados con violencia de nuestros hogares sin ser oídos y legalmente convencidos de delitos contra él, si se desprecia y obscurece nuestra inocencia antes de ser declarados culpados; es imposible asentir a la verdad de la constitución provisoria que hemos jurado, ni a la protección de las leyes que ella les asegura"102; el 13 de julio de 1819 invocando O`Higgins el art 1. cap., 2. Tit. 4 de la Constitución de 1818, que prohíbe "al poder ejecutivo intervenir en negocio alguno judicial, civil o criminal", resolvió que las habilitaciones que soliciten los menores de 25 años se hagan por el Intendente o por la cámara de justicia ${ }^{103}$; el 2 de agosto de 1819 decidió el Senado que en atención a que en "la constitución provisoria no se previene que para el caso de ausencia, enfermedades o implicancias del censor de las ciudades y villas del Estado", debía designarse un suplente104; el 22 de octubre de 1819, invocando la normativa de la "constitución provisoria", se procede a rotar la presidencia del Senado por haberse cumplido el plazo constitucional $^{105}$; 2 de septiembre de 1820, ejerciendo el Senado su facultad de reformar la Constitución, decide modificar las reglas sobre el Fiscal y sus agentes, disponiendo que el civil debe ser designado por el mismo Fiscal, creando además el agente en lo criminal, todo sujeto a lo dispuesto en la Constitución ${ }^{106}$.

Cabe recordar algunos casos de protección por parte del Senado Conservador. El 1 de Noviembre de 1818 resolvió ordenar la realización de la visita semanal de cárceles:

"con el justo fin de que el camarista, que preside el acto, tome las providencias convenientes al pronto despacho, a que deberá recomendarse el mayor cuidado sobre las prisiones y procesos, para dar cumplimiento a lo prevenido en la Constitución provisoria; y teniendo presente el art. 6. ${ }^{\circ}$, cap. I, tít. I de ella misma, y cuando por ningún motivo debe suspenderse la visita, será facultado el camarista para penar y multar al que no cumpliere con su particular y privativa obligación; y teniéndose igualmente acordado se pase semanalmente al Senado y a V.E. un estado de la visita". ${ }^{107}$

Más significativa es su decisión de 14 de noviembre de 1818:

"Se ha instruido al Senado que don Francisco Montes Larrea, graduado de coronel en el ejército, observa la conducta más terca y feroz que puede

101 Carta a José de San Martín de fecha 19 de marzo de 1819, en Epistolario de don Bernardo O`Higgins. Tomo I., ob. cit, , p. 230

102 Archivo de don Bernardo O`Higgins. Tomo XII, Imprenta Universitaria, 1953, p. 141

103 Gazeta Ministerial de Chile. Santiago, sábado 7 de agosto de 1819 , en Archivo de don Bernardo O`Higgins. Tomo XIII. Editorial Universidad Católica, 1962, p. 63

104 Gazeta Ministerial de Chile. Santiago, sábado 28 de agosto de 1819, en Archivo de don Bernardo O`Higgins. Tomo XII, op. cit., p. 97

105 Archivo de don Bernardo O`Higgins. Tomo XIII, op. cit., p. 167

106 Gazeta Ministerial de Chile. Santiago, sábado 2 de septiembre de 1820, en Archivo de don Bernardo O`Higgins. Tomo XIV. Editorial Universidad Católica., 1962, p. 61

107 Valentín Letelier, Sesiones de los Cuerpos Legislativos de Chile. Tomo II (1818-1819). 
imaginarse, en casa de don José Santos Ugarte, que éste proporcionó para su alojamiento...

La falta del prisionero y el impolítico partido que tomó de exaltarse, poniendo la casa en el mayor movimiento, hasta el extremo de herir al criado, ha sido el motivo por el que han llegado a noticia del Senado los hechos de Larrea; y teniendo a la vista lo prevenido en el artículo $1 .^{\circ}$, cap. III, tít. III de la Constitución provisoria, ha dispuesto se manifieste a V.E. que, no pudiendo disimular la infracción que hace este oficial de lo establecido en la misma Constitución, cap. I del tít. I, es preciso que V.E. se sirva reparar unos excesos que ofenden a los derechos individuales, desacreditan al Gobierno y al Estado"108.

Orrego Vicuña, siguiendo a Roldán, desarrolla en extenso en su libro de 1924, las disputas entre el Senado Conservador (designado por O`Higgins y ratificado por el mecanismo de la suscripción de la carta constitucional) y el Director Supremo ${ }^{109}$. Varios de los conflictos configuran una disputa sobre la vigencia de la Constitución provisoria de 1818 e implicaron que ambas instituciones (Senado y Ejecutivo) interpretaran sus facultades lata y laxamente para procurar imponerse una a la otra. Como ya hemos señalado el Director Supremo terminó imponiéndose al decretar el cese de sus funciones (el 22 de mayo de 1822 sesionó por última vez) y convocar a elecciones.

\subsection{Consagración de derechos individuales}

La Constitución de 1818 consagró derechos individuales, ampliando los establecidos en la Constitución de 1812, aunque fue superada en algunas regulaciones por la Constitución de 1822. El juramento de los diputados en esta carta dispone: "Artículo $42 \ldots$ ¿Juráis por Dios y por vuestro honor proceder fielmente en el desempeño de vuestras augustas funciones, dictando las leyes que mejor convengan al bien de la Nación, a la libertad politica y civil, a la seguridad individual, y de propiedades de sus individuos, y a los demás fines para que os habéis congregado, explicados en nuestra Constitución? -Sí, juro. -Sí así lo hiciereis, Dios os alumbre y defienda; y si no, responderéis a Dios y a la Nación".

La protección de la libertad personal y la integridad física, en relación con las facultades de las distintas autoridades para decretar órdenes de arresto y prisión, fueron cuestiones de particular relevancia para marcar la diferencia con la arbitrariedad propia de la "tiranía española": las personas pasaban a contar con garantías individuales o mecanismos protectores de sus bienes más preciados.

Lo propio ocurre con la libertad de comercio y de industria, cuya consagración persigue incentivar la llegada de extranjeros y dar pruebas

108 Valentín Letelier, Sesiones de los Cuerpos Legislativos de Chile , Tomo II (18181819http://es.wikisource.org/wiki/Sesiones_de_los_Cuerpos_Lejislativos_de_la_Rep\%C3\%BAblic a_de_Chile/1813/Dictamen_del_Senado_sobre_la_mejor_manera_de_proveer_a_la_seguridad_p\%C 3\%BAblica,_en_9_de_marzo_de_1813

109 El tema lo desarrolló también y con anterioridad Alcibiades Roldán, "Los desacuerdos entre O`Higgins y el Senado Conservador", en Anales de la Universidad de Chile, Tomo LXXXII, 18921893. 
concretas ante las autoridades inglesas y norteamericanas, del compromiso con la libre circulación de los bienes y los talentos.

En materia de libertad de imprenta la normativa de 1818 resulta de mayor densidad normativa que la disposición constitucional de 1812, en la medida que establece una mejor delimitación del ejercicio del derecho. Sin embargo, impone nuevas limitaciones, superándose el listado religión, costumbres y honor del país y de los ciudadanos, al incorporar los derechos particulares de los individuos, la tranquilidad pública y la Constitución. La protección de la constitución reafirma la idea según la cual la normativa constitucional es tratada como vinculante.

En materia de regulación procesal penal la Constitución de 1818 estableció, por primera vez con rango constitucional la "Autoridad Judicial", y se profundizó en la tutela constitucional de la libertad personal y la integridad fisica de los reos. Se fijaron plazos precisos para la detención y comunicación de las razones de la persecución penal, poniendo atajo a uno de las principales críticas hechas en contra de la justicia penal del Antiguo Régimen ${ }^{110}$.

Dentro de las diferencias relevantes está la regulación del derecho de propiedad, que alcanzó su mayor protección en la carta de 1822, marcando una diferencia sustantiva también con la regulación del año 1812.

Un cuadro comparativo muestra lo siguiente

Tabla 1.

\begin{tabular}{|c|c|c|}
\hline Carta de 1812 & Carta de 1818 & Carta de 1822 \\
\hline $\begin{array}{l}\text { Libertad de residencia y } \\
\text { movimiento }\end{array}$ & $\begin{array}{l}\text { Libertad de residencia y } \\
\text { movimiento }\end{array}$ & \\
\hline \multicolumn{3}{|l|}{ Derecho de asilo } \\
\hline & $\begin{array}{llll}\begin{array}{l}\text { Derecho } \\
\text { personal }\end{array} & \text { a } & \text { la } & \text { honra } \\
\end{array}$ & \\
\hline & Propiedad individual & Propiedad individual \\
\hline & & Libertad de industria \\
\hline & $\begin{array}{lll}\begin{array}{l}\text { Inviolabilidad de } \\
\text { correspondencia }\end{array} & \text { la } \\
\end{array}$ & $\begin{array}{ll}\text { Inviolabilidad de la } \\
\text { correspondencia }\end{array}$ \\
\hline & Estabilidad funcionaria & Estabilidad funcionaria \\
\hline \multirow[t]{2}{*}{$\begin{array}{l}\text { Garantías del proceso } \\
\text { penal }\end{array}$} & $\begin{array}{l}\text { Garantías del proceso } \\
\text { penal }\end{array}$ & $\begin{array}{l}\text { Garantías del proceso } \\
\text { penal }\end{array}$ \\
\hline & $\begin{array}{l}\text { El Titulo Primero lleva } \\
\text { por título: De los } \\
\text { derechos del hombre en } \\
\text { sociedad, consagró que } \\
\text { los hombres gozan de un } \\
\text { derecho inajenable... a su } \\
\text { seguridad individual, } \\
\text { honra, hacienda, libertad } \\
\text { e igualdad civil }\end{array}$ & $\begin{array}{l}\text { Reguló en los artículos } \\
198 \text { y ss. las "garantías } \\
\text { individuales" }\end{array}$ \\
\hline Libertad personal & $\begin{array}{lcc}\text { Libertad } & \text { personal } & y \\
\text { limitación } & \text { del régimen } & \text { de }\end{array}$ & $\begin{array}{lcc}\text { Libertad } & \text { personal } & y \\
\text { limitación } & \text { al régimen } & \text { de }\end{array}$ \\
\hline
\end{tabular}

110 Por todos, véase: Eric Palma González, "La crítica liberal a la judicatura del crimen: España 1810-1812", Anuario Iberoamericano de Historia del Derecho e Historia Contemporánea, pp., 99114, Santiago de Chile, 2001 


\begin{tabular}{|l|l|l|}
\hline & esclavitud & esclavitud \\
\hline & Libertad civil & $\begin{array}{l}\text { La libertad de las } \\
\text { conversaciones privadas }\end{array}$ \\
\hline Seguridad individual; & Seguridad individual & Seguridad individual \\
\hline Dignidad & Dignidad humana & Libertad de expresión y \\
\hline Libertad de imprenta & Libertad de imprenta & $\begin{array}{l}\text { de libre circulación de } \\
\text { impresos ante la ley }\end{array}$ \\
\hline Igualdad de derecho & Igualdad civil & Igualdad ante la \\
\hline
\end{tabular}

\subsection{Consagración de deberes del Estado para con las clases populares, así como de los individuos en la vida social}

La carta de 1818 inauguró en Chile la idea de un estado constitucional con una vertiente social al disponer en su artículo 13 el deber de la autoridad pública estatal de "aliviar la miseria de los desgraciados y proporcionarle a todos los caminos de la prosperidad ${ }^{111}$; establecer el derecho a la estabilidad en el empleo y el reconocimiento de la antigüedad y los servicios como únicos criterios para la promoción ${ }^{112}$; no avanzó en materia de educación como si lo hizo en la Carta de 1822 regulando la educación pública ${ }^{113}$.

La Constitución de 1818 consagró el principio moral "no hagas a otro lo que no quieras que hagan contigo" y estableció para los que aspiraran a ser verdaderos patriotas un conjunto de cualidades morales: "virtuoso, honrado, benéfico, buen padre de familia, buen hijo, buen amigo, buen soldado"114.

111 "Todo individuo de la sociedad tiene el incontestable derecho a ser garantido en el goce de su tranquilidad y felicidad por el Director Supremo y demás funcionarios públicos del Estado, quienes están esencialmente obligados a aliviar la miseria de los desgraciados y proporcionarle a todos los caminos de la prosperidad".

112 En el Título IV. Capítulo I, artículo 13: "La duración de todo empleado, a no ser de los exceptuados en esta Constitución, será de su buena comportación, y deberá ser removido siendo inepto o delincuente, con causa probada y audiencia suya"; y respecto de los nombramientos se dispuso en el artículo 11 que la propuesta de nombramiento para empleo que hagan los jefes de servicio debe ajustarse a la escala de antigüedad y servicios, publicándose dicha propuesta en la oficina o departamento ocho días antes de remitirla al Director, quedando así a los agraviados franco el recurso de sus derechos a la autoridad que corresponda; lo mismo se dispuso respecto de los ascensos en los Cabildos Eclesiásticos los que "debian proveerse por la escala de antigüedad y servicio".

113 Fernando Campos Harriet, en Historia Constitucional de Chile, op. cit., p. 435 califica este normativa como "principios sociales adelantados para la época".

114 "Título Primero, Capítulo II, De los deberes del hombre social. Artículo 1.Todo hombre en sociedad, para afianzar sus derechos y fortuna, debe completa sumisión a la Constitución del Estado, a sus Estatutos y Leyes, haciendo lo que ellas prescriben y huyendo de lo que prohíben. Artículo 2. Debe obedecer, honrar y respetar a todos los magistrados y funcionarios públicos como ministro de la ley y primeros ciudadanos. Artículo 3. Debe igualmente ayudar con alguna porción de sus bienes para los gastos ordinarios del Estado; y en sus necesidades extraordinarias y peligros debe sacrificar lo más estimable por conservar su existencia y libertad. Artículo 4. Está obligado a dirigir sus acciones respecto de los demás hombres, por aquel principio moral: no hagas a los otros lo que no quieras que hagan contigo. Artículo 5. Todo individuo que se glorie de verdadero patriota debe llenar las obligaciones que tiene para con Dios y los hombres, siendo virtuoso, honrado, benéfico, buen padre de familia, buen hijo, buen amigo, buen soldado, obediente a la ley y funcionario fiel, desinteresado y celoso". 
Se exigía de los senadores "acendrado patriotismo, integridad, prudencia, sigilo, amor a la justicia y bien público"; del Director Supremo "verdadero patriotismo, integridad, talento, desinterés, opinión pública y buenas costumbres"; y de los jueces "integridad, amor a la justicia, desinterés, literatura y prudencia”.

Por su parte la Carta de 1822 estableció en su artículo $8^{\circ}$ y $9^{\circ}$ una disposición semejante: “Todos deben contribuir para los gastos del Estado en proporción de sus haberes; Todo chileno debe llenar las obligaciones que tiene para con Dios y los hombres, siendo virtuoso, honrado, benéfico, buen padre de familia, buen hijo, buen amigo, buen soldado, obedeciendo a la Constitución y a la ley, y funcionario fiel, desinteresado y celoso".

Estas virtudes remiten a las virtudes del buen cristiano actuando en política, pero también, al ideario republicano según el cual el éxito de la vida en sociedad está vinculado al respeto y amor a las leyes y a la patria, y en hacer predominar el bien público por sobre el individual, dando pie para reflexionar si pudo haber algo más que un gobierno representativo o una "república formal" antitética de la Monarquía ${ }^{115}$.

\subsection{Constitución y nación}

La Carta chilena de 1812 se refiere en el preámbulo a la Nación española y a Chile, identificado como patria, incorporado en dicha Nación.

La Constitución de 1818 se refiere en el preámbulo a la Nación chilena. O`Higgins excusa no poder consultar, aunque lo desea, "la voluntad general sobre el negocio que más interesa a la Nación".

El Título III, De la Potestad Legislativa, Capítulo I, artículo único dispone: "Artículo Único.- Perteneciendo a la Nación chilena reunida en sociedad, por un derecho natural e inamisible, la soberanía o facultad para instalar su Gobierno y dictar las leyes que le han de regir, lo deberá hacer por medio de sus Diputados reunidos en Congreso".

Por su parte la Carta de 1822 dispuso por primera vez:

"Título I. De la Nación chilena y de los chilenos. Capítulo I. De la Nación chilena. Artículo 1.- La Nación Chilena es la unión de todos los chilenos: en ella reside esencialmente la soberanía, cuyo ejercicio delega conforme a esta Constitución. Artículo 2.- La Nación Chilena es libre e independiente de la Monarquía española y de cualquiera otra potencia extranjera: pertenecerá sólo a sí misma, y jamás a ninguna persona ni familia".

Y modificando el juramento que debian hacer las autoridades de obediencia a la Constitución señaló:

115 José Aguilar, "Dos conceptos de República", en José Aguilar y Jorge Rojas edit. El Republicanismo en Hispanoamérica. Ensayos de historia intelectual y política, editorial Fondo de Cultura Económica. Centro de Investigación y Docencia Económicas. México, 2002.

Eduardo Rozo Acuña, Simón Bolivar, op. cit., ha llamado la atención, a propósito del estudio del pensamiento de Simón Bolivar, sobre el papel de la virtud como indicativo de una idea de libertad que se aleja del liberalismo burgués y se acerca a la idea de libertad de los antiguos. 
"Artículo 42.- Los Diputados, el día en que se abra el Congreso, jurarán ante la Corte de Representantes, el Director Supremo y el Supremo Tribunal de Justicia en la forma siguiente: “¿Juráis por Dios y por vuestro honor proceder fielmente en el desempeño de vuestras augustas funciones, dictando las leyes que mejor convengan al bien de la Nación, a la libertad politica y civil, a la seguridad individual, y de propiedades de sus individuos, y a los demás fines para que os habéis congregado, explicados en nuestra Constitución? -Sí, juro. -Sí así lo hiciereis, Dios os alumbre y defienda; y si no, responderéis a Dios y a la Nación".

La carta de 1818 hacía mención a la Patria y ninguna a la Nación. 1822.

La voz Nación aparece empleada en numerosas ocasiones en la carta de

\subsection{Constitución sin ciudadanos}

No todas las constituciones regulan la ciudadanía. Las Cartas de 1812 y de 1818 no tienen disposiciones relativas a esta materia.

El reglamento plebiscitario que reguló la aprobación de la Constitución de 1818 mediante el mecanismo de la suscripción, estableció que tendrían derecho a suscribir los padres de familia, o que tengan algún capital o ejerzan algún oficio, y que no se hallen con causa pendiente de infidencia, o de dividir la voluntad de los otros.

En octubre de 1819 se hizo notar por parte del procurador general de la ciudad, que la "constitución provisoria" no contemplaba las formalidades para declarar ciudadanos a los extranjeros, ni los requisitos para otorgar este "honroso título", ya sea respecto de los españoles como respecto de cualquiera otro extranjero, y se solicitó al Director Supremo remediar este vacío ${ }^{116}$.

La primera Constitución que reguló la ciudadanía fue la de 1822 en el Capítulo II (De los ciudadanos), Título III Del Gobierno y de los Ciudadanos) ${ }^{117}$.

Como es evidente la regulación constitucional de la ciudadanía, aunque del tipo censitaria y distinguiendo entre pasiva y activa (según se tenga o no acceso a todos los derechos políticos) puso al individuo en un plano distinto al del vasallo en la relación con el poder, y debilita, política y jurídicamente, la concentración del poder en unos pocos.

116 Archivo de don Bernardo O’Higgins. Tomo XIII, op. cit., 1962, pp. 168-169

La ausencia de norma constitucional en esta materia fue criticada en el diario El Sol y a juicio de Orrego Vicuña era uno de los principales defectos de la Carta de 1818.

117 "Artículo 14. Son ciudadanos todos los que tienen las calidades contenidas en el artículo $4^{\circ}$ -regula a los chilenos-, con tal que sean mayores de veinticinco años o casados, y que sepan leer y escribir, pero esta última calidad no tendrá lugar hasta el año de 1833. Artículo 15. Pierden la ciudadania: $1^{\circ}$. Los que adquieren naturaleza en país extranjero; $2^{\circ}$. Los que admitan empleo de otro Gobierno; $3^{\circ}$. Los que son condenados a pena aflictiva o infamante, si no obtienen rehabilitación; $4^{\circ}$ Los que residiesen cinco años continuos fuera de Chile, sin licencia del Gobierno. Artículo 16. La ciudadanía se suspende. $1^{\circ}$ En virtud de interdicción judicial, por incapacidad moral o física; $2^{\circ}$. En el deudor quebrado; $3^{\circ}$. En el deudor a los caudales públicos; $4^{\circ}$. En el sirviente doméstico asalariado; $5^{\circ}$ En el que no tiene modo de vivir conocido; $6^{\circ}$. En el que se haya procesado criminalmente". 


\subsection{Constitución sin indigenas}

La carta de 1818 no tiene ninguna regulación al respecto, tampoco hubo en la Carta de 1812 chilena. Sin embargo, en el plano legal O'Higgins estableció la plena igualdad entre todos los chilenos: los indios fueron considerados ciudadanos chilenos y libres como los demás habitantes del Estado con igual voz y representación.

La Carta de 1822 disponía en relación con esta materia en el artículo 47 número 6: "Corresponde al Congreso: cuidar de la civilización de los indios del territorio".

\subsection{Consagración de la libertad de los esclavos (vientres libres)}

En materia de promoción de la libertad y dignidad humana, el Congreso Nacional declaró el 11 de octubre de 1811 que los hijos de esclavos que nacieran en territorio chileno serian libres, así como todo aquel que venido del extranjero permaneciera, por cualquier causa, por 6 meses en nuestro país.

La carta de 1818 dispuso en su "Artículo 12. Subsistirá en todo vigor la declaración de los vientres libres de las esclavas, dada por el Congreso, y gozarán de ella todos los de esta clase nacidos desde su promulgación”.

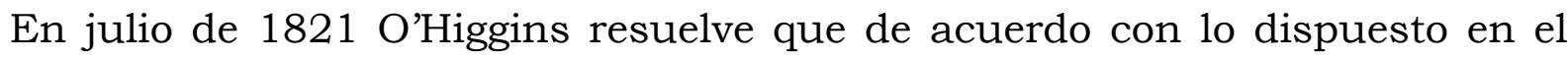
artículo 12 , capítulo $1^{\circ}$, título $1^{\circ}$ de la Constitución, debe observarse fielmente la disposición del año 1811.

La Carta de 1822 no tiene regla alguna en esta materia118.

\subsection{Regulación constitucional del Cabildo}

La Carta de 1812 establecía en su "Artículo XII.- Los Cabildos serán electivos, y sus individuos se nombrarán anualmente por suscripción". No estatuyó sus atribuciones.

La Constitución de 1818 dedicó el Capítulo VI a los cabildos regulando el fuero de sus miembros; los fines de la institución ("deberán fomentar el adelantamiento de la población, industria, educación de la juventud, hospicios, hospitales y cuanto sea interesante al beneficio público"), así como la policía urbana; su patrimonio; y la elección y labor de los asesores.

La carta de 1822 es mucho más sucinta, cuenta con un capitulo que lleva por título De los cabildos. Establece la figura del delegado directorial, que pasó a presidir el cabildo y regula el fuero. El deterioro de regulación y autonomía es evidente.

118 Para el contraste de la regulación en otras constituciones, véase con provecho de Carlos Petit,"negros y mulatos españoles de ambos hemisferios", en Historia Constitucional, n. 15, 2014., pp. $155-204$

Para el fenómeno de la abolición en el estado constitucional, véase Eric Eduardo Palma G, coord., Abolición de la esclavitud en el constitucionalismo del siglo XIX: Colombia, Chile, Perú y Portugal, Editorial Jurídica de Chile, junio de 2016, 157 pp 


\subsection{Congreso Nacional unicameral}

En la Carta de 1812 y de 1818 se establecía como órgano legislativo un Senado compuesto por 7 personas en el primer caso y en el segundo por 5 . En la Constitución de 1812 se contemplaba su elección por provincias y en 1818 fueron designados por el Ejecutivo.

La Constitución de 1822 fue la primera en establecer un Congreso bicameral, sin embargo, el Senado, que sólo se reúne cada dos años, se compone con miembros designados.

\subsection{Regulación del derecho constitucional de excepción}

En las constituciones de 1812, 1818, 1822 se acepta la existencia de un derecho constitucional de excepción, presentándose diferencias en lo tocante a las facultades otorgadas y a los derechos lesionados. No existe la medida de suspensión general de la vigencia de la Constitución y no se contempla la institución del estado de sitio $^{119}$. Se admite la atribución a la autoridad política de facultades extraordinarias sujetas a revisión por la autoridad legislativa.

La Constitución de 1812 en su artículo 26 contempló implícitamente la posibilidad de la suspensión de ciertas normas del Reglamento Constitucional, sin rodear dicha decisión de formalidad alguna, de hecho, no se estableció la autoridad competente para hacerlo: "Artículo 26. Sólo se suspenderán todas estas reglas invariables en el caso de importar a la salud de la patria amenazada: pero jamás la responsabilidad del que las altere sin grave motivo".

Muy distinta es la regulación del año 1818 que en su artículo 5, Título primero, Capítulo primero dispuso ante "casos urgentes", y por decisión del Senado, la suspensión de la norma que garantizaba la inviolabilidad del domicilio; también en su artículo 8 del Título IV, Capítulo II, pero esta vez por decisión del Ejecutivo, y ante necesidades de la "salud general y bien del Estado", se admitió la intercepción y apertura de la "correspondencia epistolar"; y en el Título V, Capítulo III, la suspensión de las normas sobre prisión. Señalaba el artículo 20: "No deberá esta inmunidad tener lugar cuando haya algún peligro inminente de la Patria". En atención a estas reglas el Senado resolvió el 17 de noviembre de 1818:

"se vio la consulta del Excmo. Señor Supremo Director sobre los arts. $2^{\circ}$ y $8^{\circ}$, cap. I, tít. IV de la Constitución provisoria; y acordó S. E. que estando al contexto del art. 21 del cap. III, tít. .III de la misma Constitución, se dijera al señor Director que no debiendo tener lugar aquellas disposiciones mediando peligro eminente contra la Patria y que siendo la suprema ley la salud pública, la misma Constitución y el Senado autorizaban a S. E. para que, por medio de una Comisión, se tratara de la investigación de los crímenes y

119 Véase para este tema, Eric Palma González, El derecho de excepción en el primer constitucionalismo español, editorial, Universidad de Valladolid. Secretariado de publicaciones, 2000; “El estado de sitio en las Cortes de Cádiz y el Trienio Liberal" revista, Investigaciones Históricas: Época moderna y contemporánea, No. 21, 2001, pp. 181-204; ¿Gobierno Portaliano o Gobierno Conservador Autoritario?: de los mecanismos constitucionales para garantizar la eficacia del ejercicio del poder en la constitución de 1833", Revista de Derecho, núm., 13, 2002, pp., 45-64 
autores contra el sosiego del Estado para escarmentarles en debida forma"120.

Habiéndose omitido la firma del Ministro del ramo pertinente en un acto de Gobierno, lo que anulaba la decisión, el Senado representó a O’Higgins esta situación. El Director Supremo contestó, señala Roldán, que estaba dotado de un poder discrecional: "respetando la Constitución, se hallaba resuelto a separarse de ella si algún deber imperioso, aconsejado por la salud pública, se lo aconsejaba"121, respuesta que fue rechazada por el Senado invocando el absoluto respeto que todos debían a la ley y a la totalidad de la Constitución: "No está en el orden que el alto poder sea alguna vez discrecional. Siempre es sujeto a la ley, y si en alguna circunstancia debe ceder ésta, debe ser sólo cuando peligre la salud de la patria y entonces con acuerdo del mismo poder legislativo" ${ }^{22}$.

La Carta de 1822 reguló en su artículo 121 el otorgamiento por el legislativo de "facultades extraordinarias" ante "un peligro inminente del Estado" y por el tiempo que dure la necesidad, "sin que por ningún motivo haya la menor prórroga".

El 20 de enero de 1823, ante la situación convulsionada del país que terminó con la caída de O`Higgins, se invocó por la Corte de Representantes el artículo 67 de la Constitución y se convocó a sesiones extraordinarias del Congreso para conocer la voluntad general.

\subsection{Reforma Constitucional}

Respecto de la modificación de la Constitución no hubo una regulación homogénea. La carta de 1812 señaló que correspondía a la Junta Superior Gubernativa con acuerdo del Senado.

En cambio, en la Constitución de 1818, Título III, Capítulo III, artículo 5, se dispuso: "Estará autorizado el Senado para limitar, añadir y enmendar esta Constitución provisoria, según lo exijan las circunstancias".

\footnotetext{
120Valentín Letelier, Sesiones de los Cuerpos Legislativos de Chile, Tomo II (1818-1819): "Aunque en el orden general y rutina de los juicios criminales, tengan término designado sus trámites ordinarios, señalándose jueces competentes para sus respectivos grados e instancias, y aunque la inmunidad del hombre que vive en sociedad deba ser protegida mientras no hay prueba de delito demostrada, al menos en sumario, terminándose a esto mismo la disposición de nuestra Constitución provisoria; como ocurren casos en que, por observarse esa ritualidad y formalidades, puede perturbarse el orden público y embarazarse la severidad de los castigos, según lo exigen las circunstancias; por eso les previene el art. 21 del cap. III, tít. V no tener lugar aquellas disposiciones cuando haya algún peligro inminente de la patria.

V. E. advierte al Senado hallarse en este caso y siendo como es la salud pública una ley suprema, la misma Constitución y el Senado autorizan desde luego a V. E. para que, por medio de una comisión, se resuelvan del modo posible los crímenes y autores de que habla la nota de esta fecha, a fin de que escarmienten como corresponde y que, restituido el orden y la tranquilidad, no experimente después el Estado iguales convulsiones. —Dios guarde a V. E. —Santiago, Noviembre 16 de 1818.
}

121 Alcibiades Roldán, Los desacuerdos, op. cit., 202

122 Ibid 
La Constitución de 1822 señalaba en su artículo 246: "Las leyes fundamentales de esta Constitución no podrán variarse sin expresa orden de los pueblos, manifestada solemnemente a sus representantes".

La cámara representativa era la de diputados por tanto en ellos recae la responsabilidad de la presentación del proyecto de reforma constitucional.

\subsection{Constitucionalización del proceso penal}

Esta normativa será la que otorgue mayor legitimidad al discurso que promueve la transformación del orden político institucional: el gobierno representativo no hereditario y la constitución, garantizaban la seguridad del individuo ante la arbitrariedad política y judicial, y amparaban la libertad personal ${ }^{123}$.

De la lectura de las constituciones de 1812, 1818 y 1822, se desprende que desde el Reglamento Constitucional hay un relevante grado de continuidad en la consagración de derechos, así como progresión en una mayor densidad normativa y mejor técnica legislativa (lo que no excluye algunos retrocesos).

Tabla 2 regulación del proceso penal

\begin{tabular}{|c|c|c|c|}
\hline Regulación normativa & $\begin{array}{l}\text { Reglamento } \\
\text { Constitucional } \\
\text { Provisorio de } 1812\end{array}$ & $\begin{array}{l}\text { Constitución } \\
\text { Provisoria de } 1818\end{array}$ & Constitución de 1822 \\
\hline $\begin{array}{l}\text { 1. Derecho a ser } \\
\text { considerado inocente } \\
\text { mientras no se dicte la } \\
\text { sentencia } \\
\text { condenatoria definitiva }\end{array}$ & & $\begin{array}{l}\text { Titulo Primero } \\
\text { De los derechos y } \\
\text { deberes del hombre en } \\
\text { sociedad } \\
\text { Capítulo Primero, } \\
\text { De los derechos del } \\
\text { hombre en sociedad } \\
\text { Articulo 3: "Todo } \\
\text { hombre se reputa } \\
\text { inocente, hasta que } \\
\text { legalmente sea } \\
\text { declarado culpado". }\end{array}$ & \\
\hline $\begin{array}{l}\text { 2. Derecho a la libertad } \\
\text { provisional, salvo por } \\
\text { delito que merezca } \\
\text { pena aflictiva }\end{array}$ & & $\begin{array}{l}\text { Título Primero... } \\
\text { Artículo } 4^{\circ} \text {. - El hombre } \\
\text { que afianza la } \\
\text { existencia de su } \\
\text { persona y bienes, a } \\
\text { satisfacción del juez, } \\
\text { con una seguridad } \\
\text { suficiente, no debe ser } \\
\text { preso ni embargado, a } \\
\text { no ser que sea por } \\
\text { delito que merezca } \\
\text { pena aflictiva. }\end{array}$ & $\begin{array}{l}\text { Capitulo } I V \\
\text { Articulo 202.- A nadie } \\
\text { se pondrá preso por } \\
\text { delito que no merezca } \\
\text { pena corporal o de } \\
\text { destierro, y sin que } \\
\text { preceda mandamiento } \\
\text { de prisión por escrito, } \\
\text { que se notificará en el } \\
\text { acto de ella. }\end{array}$ \\
\hline & & $\begin{array}{l}\text { Capitulo III, Título V, } \\
\text { De la Autoridad }\end{array}$ & $\begin{array}{l}\text { Articulo 207.- En } \\
\text { cualquier estado de la } \\
\text { causa, en que se }\end{array}$ \\
\hline
\end{tabular}

123 Eric Palma González, La Constitucionalización del proceso penal en Chile y sus alcances en la doctrina y la práctica procesal del siglo XIX, Colección de Investigaciones Jurídicas, Universidad Alberto Hurtado, 2004, 117 pp. 


\begin{tabular}{|c|c|c|c|}
\hline & & $\begin{array}{l}\text { Judicial. "Artículo } 22 . \\
\text { Ningún ciudadano ha } \\
\text { de ser asegurado con } \\
\text { prisiones, si no se } \\
\text { recela su fuga"; }\end{array}$ & $\begin{array}{l}\text { advierta que el delito } \\
\text { no merece penas } \\
\text { corporal o } \\
\text { destierro, se pondrá } \\
\text { libre al preso. }\end{array}$ \\
\hline $\begin{array}{l}\text { 2.Derecho a ser } \\
\text { juzgado según proceso } \\
\text { fijado por la ley }\end{array}$ & $\begin{array}{l}\text { Artículo } \\
\text { Ninguno será penado } \\
\text { sin proceso } \\
\text { sentencia conforme a } \\
\text { la ley. }\end{array}$ & $\begin{array}{l}\text { Titulo Primero... } \\
\text { Articulo } 2^{\circ} . \text { Ninguno } \\
\text { debe ser castigado o } \\
\text { desterrado, sin que } \\
\text { sea oído y legalmente } \\
\text { convencido de algún } \\
\text { delito contra el cuerpo } \\
\text { social }\end{array}$ & $\begin{array}{l}\text { Capitulo } I V \\
\text { Articulo 205.- Todo } \\
\text { acto ejercido contra un } \\
\text { hombre fuera del caso, } \\
\text { y sin las formalidades } \\
\text { que la ley prescribe, es } \\
\text { arbitrario y tiránico. }\end{array}$ \\
\hline $\begin{array}{l}\text { 2.Derecho a que la } \\
\text { orden que afecta la } \\
\text { seguridad personal, de } \\
\text { la casa, efectos y } \\
\text { papeles se funde en } \\
\text { una causa probable } \\
\text { sostenida } \\
\text { judicialmente, }\end{array}$ & $\begin{array}{l}\text { Artículo XVI: “... no se } \\
\text { darán órdenes sin } \\
\text { causas probables, } \\
\text { sostenidas por un } \\
\text { juramento judicial”. } \\
\text { Artículo XIX.- Nadie } \\
\text { será arrestado sin } \\
\text { indicios vehementes } \\
\text { de delito, o a lo menos } \\
\text { sin una semiplena } \\
\text { prueba. La causa se } \\
\text { hará constar antes de } \\
\text { tres dias perentorios: } \\
\text { dentro de ellos se hará } \\
\text { saber al interesado. }\end{array}$ & $\begin{array}{l}\text { En el Capítulo III, } \\
\text { Título V, De la } \\
\text { Autoridad Judicial se } \\
\text { estableció". "Artículo } \\
\text { 20. Ningún ciudadano } \\
\text { podrá ser preso sin } \\
\text { precedente semi-plena } \\
\text { probanza de su delito, }\end{array}$ & \\
\hline $\begin{array}{l}\text { 3.Derecho a que la } \\
\text { orden identifique } \\
\text { precisamente la } \\
\text { persona a arrestar; el } \\
\text { objeto o el domicilio a } \\
\text { examinar }\end{array}$ & $\begin{array}{l}\text { Artículo XVI:”... no se } \\
\text { darán órdenes sin } \\
\text { designar con claridad } \\
\text { los lugares o cosas } \\
\text { que se han de } \\
\text { examinar } \\
\text { aprehender" }\end{array}$ & & \\
\hline $\begin{array}{l}\text { 4.Derecho a que el } \\
\text { arresto decretado por } \\
\text { el poder politico sea } \\
\text { conocido en breve } \\
\text { plazo por el juez }\end{array}$ & & $\begin{array}{l}\text { Título IV, Capítulo II, } \\
\text { artículo 2, se señaló } \\
\text { respecto del Ejecutivo: } \\
\text { "Cuando la urgencia } \\
\text { del caso obligue a } \\
\text { arrestar alguna } \\
\text { persona, deberá } \\
\text { ponerla dentro de } \\
\text { veinticuatro horas a } \\
\text { disposición de los } \\
\text { respectivos } \\
\text { magistrados } \\
\text { justicia, con toda la } \\
\text { independencia } \\
\text { corresponde al Poder } \\
\text { Judicial...". }\end{array}$ & $\begin{array}{l}\text { Capítulo II. Facultades } \\
\text { y limites del Poder } \\
\text { Ejecutivo } \\
\text { Artículo 117.- A } \\
\text { ninguno privará de su } \\
\text { libertad ni le castigará } \\
\text { con pena alguna por } \\
\text { sí el Ministro que } \\
\text { firmase orden para } \\
\text { esto y la autoridad que } \\
\text { la ejecute, serán } \\
\text { responsables a la } \\
\text { Nación como de un } \\
\text { grave atentado contra } \\
\text { la seguridad } \\
\text { individual. }\end{array}$ \\
\hline $\begin{array}{l}\text { 5. Derecho a ser } \\
\text { notificado de la orden } \\
\text { de prisión. }\end{array}$ & & $\begin{array}{l}\text { Título IV, Capítulo II, } \\
\text { artículo 2: “... antes de } \\
\text { ocho dias } \\
\text { hacérsele debe } \\
\text { causa saber } \\
\text { prisión...". }\end{array}$ & $\begin{array}{l}\text { Capitulo } I V \\
\text { Artículo 202.- A nadie } \\
\text { se pondrá preso por } \\
\text { delito que no merezca } \\
\text { pena corporal o de } \\
\text { destierro, y sin que }\end{array}$ \\
\hline
\end{tabular}




\begin{tabular}{|c|c|c|c|}
\hline & & & $\begin{array}{l}\text { preceda mandamiento } \\
\text { de prisión por escrito, } \\
\text { que se notificará en el } \\
\text { acto de ella. }\end{array}$ \\
\hline $\begin{array}{l}\text { 6. Derecho a conocer } \\
\text { la causa de la prisión } \\
\text { después de un plazo } \\
\text { desde que esta se } \\
\text { ejecutó. }\end{array}$ & $\begin{array}{l}\text { Artículo XIX.- "La } \\
\text { causa se hará constar } \\
\text { antes de tres dias } \\
\text { perentorios: dentro de } \\
\text { ellos se hará saber al } \\
\text { interesado. }\end{array}$ & $\begin{array}{l}\text { Capitulo III, Título V, } \\
\text { De la Autoridad } \\
\text { Judicial se estableció: } \\
\text { "Artículo 20. “.. y } \\
\text { antes de ocho dias } \\
\text { debe hacérsele saber } \\
\text { la causa de su } \\
\text { prisión". } \\
\text { Título IV, Capítulo II, } \\
\text { artículo 2, se señaló } \\
\text { respecto del Ejecutivo } \\
\text { que decretaba un } \\
\text { arresto "que debía dar } \\
\text { a conocer al juez los } \\
\text { motivos para su } \\
\text { juzgamiento". }\end{array}$ & $\begin{array}{l}\text { Capitulo IV } \\
\text { Articulo 206.- Cuando } \\
\text { el delincuente no sea } \\
\text { sorprendido infraganti, } \\
\text { debe preceder a su } \\
\text { prisión la sumaria; si } \\
\text { es infraganti, debe } \\
\text { estar hecha a los dos } \\
\text { dias. } \\
\text { Artículo 208.- A todo } \\
\text { preso antes de } \\
\text { cuarenta y ocho horas } \\
\text { de su prisión, se le } \\
\text { hará saber el motivo } \\
\text { de ella. } \\
\text { Articulo 209.- El } \\
\text { alcaide llevará un libro } \\
\text { en que asiente el dia, } \\
\text { hora y motivo de la } \\
\text { prisión y el nombre del } \\
\text { juez que la decretó }\end{array}$ \\
\hline $\begin{array}{l}\text { 7, Derecho a que se } \\
\text { embarguen sólo los } \\
\text { bienes necesarios y a } \\
\text { que no se confisquen } \\
\text { los bienes como pena }\end{array}$ & & $\begin{array}{l}\text { Capitulo III. Artículo } \\
\text { 23. Tampoco podrán } \\
\text { embargársele más } \\
\text { bienes que los precisos } \\
\text { para responder por el } \\
\text { delito, y si fuere de } \\
\text { calidad que exija } \\
\text { alguna pena } \\
\text { pecuniaria"; }\end{array}$ & $\begin{array}{l}\text { Capitulo IV } \\
\text { Artículo 216.- Queda } \\
\text { abolida la pena de } \\
\text { confiscación de bien } \\
\text { Artículo 217.- Nunca } \\
\text { se decretará embargo, } \\
\text { si no es en los casos } \\
\text { que piden restitución, } \\
\text { multa o pago; pero } \\
\text { ofreciéndose fianza } \\
\text { abonada de juzgado y } \\
\text { sentenciado, se } \\
\text { suspenderá } \\
\text { embargo, que en } \\
\text { ningún caso podrá } \\
\text { exceder de la cantidad } \\
\text { necesaria al cubierto } \\
\text { de la deuda o pena. }\end{array}$ \\
\hline $\begin{array}{l}\text { 8. Derecho a la } \\
\text { integridad fisica y a no } \\
\text { ser sometido a tortura }\end{array}$ & 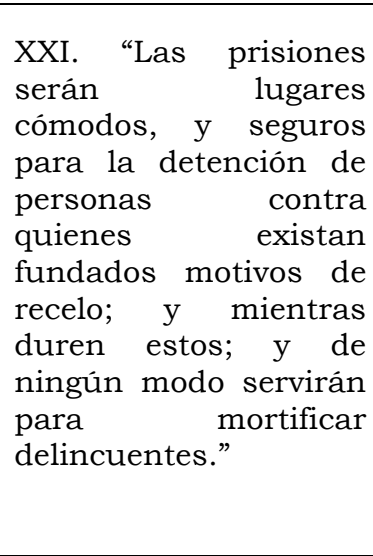 & $\begin{array}{l}\text { Capitulo Primero } \\
\text { Articulo } 6^{\circ} . \text { Un juez } \\
\text { que mortifica a un } \\
\text { preso más de lo que } \\
\text { exige su seguridad y } \\
\text { entorpece la breve } \\
\text { conclusión de su } \\
\text { causa es un } \\
\text { delincuente, como } \\
\text { igualmente } \\
\text { magistrados que no } \\
\text { cuidan del aseo de las } \\
\text { cárceles, alimento, y el } \\
\text { alivio de los presos. } \\
\text { Articulo } 8^{\circ} \text {.- Sólo será }\end{array}$ & $\begin{array}{l}\text { Capitulo IV } \\
\text { Articulo 215.- A } \\
\text { ninguno se pondrá } \\
\text { grillos sin orden del } \\
\text { juez, por escrito, quien } \\
\text { sólo podrá darla } \\
\text { cuando se tema fuga. }\end{array}$ \\
\hline
\end{tabular}




\begin{tabular}{|c|c|c|c|}
\hline & & $\begin{array}{l}\text { castigado con la pena } \\
\text { infame de azotes, el } \\
\text { que por la repetición o } \\
\text { publicidad de sus } \\
\text { delitos, haya perdido } \\
\text { la honra, y el juez que } \\
\text { esto no observe será } \\
\text { responsable. } \\
\text { Artículo 15.- Es } \\
\text { injusta la pena } \\
\text { dirigida a aumentar la } \\
\text { sensibilidad y dolor } \\
\text { fisico. } \\
\text { Artículo 16.- Deben } \\
\text { evitarse las penas de } \\
\text { efusión de sangre en } \\
\text { cuanto lo permita la } \\
\text { seguridad pública. }\end{array}$ & \\
\hline $\begin{array}{l}\text { 9. Derecho a ser } \\
\text { juzgado por un } \\
\text { tribunal competente } \\
\text { según } \\
\text { procedimiento fijado } \\
\text { por la ley } r \text { con } \\
\text { anterioridad al hecho } \\
\text { que se juzga }\end{array}$ & & $\begin{array}{l}\text { Titulo Primero... } \\
\text { Articulo } 2^{\circ} \text {.- Ninguno } \\
\text { debe ser castigado o } \\
\text { desterrado, sin que } \\
\text { sea oído y legalmente } \\
\text { convencido de algún } \\
\text { delito contra el cuerpo } \\
\text { social. }\end{array}$ & $\begin{array}{l}\text { Capítulo II. Facultades } \\
\text { y limites del Poder } \\
\text { Ejecutivo } \\
\text { Artículo 117.- A } \\
\text { ninguno privará de su } \\
\text { libertad ni le castigará } \\
\text { con pena alguna por } \\
\text { sí el Ministro que } \\
\text { firmase orden para } \\
\text { esto y la autoridad que } \\
\text { la ejecute, serán } \\
\text { responsables a la } \\
\text { Nación como de un } \\
\text { grave atentado contra } \\
\text { la seguridad } \\
\text { individual. } \\
\text { Capitulo IV...Artículo } \\
\text { 199.- Todos serán } \\
\text { juzgados en causas } \\
\text { civiles y criminales por } \\
\text { sus jueces naturales, y } \\
\text { nunca por comisiones } \\
\text { particulares. }\end{array}$ \\
\hline $\begin{array}{l}\text { 10. Derecho a no ser } \\
\text { mantenido en } \\
\text { incomunicación } \\
\text { prolongada mientras } \\
\text { se es juzgado. }\end{array}$ & $\begin{array}{l}\text { Artículo XX.- "No } \\
\text { podrá estar alguno } \\
\text { incomunicado después } \\
\text { de su confesión, y se } \\
\text { tomará precisamente } \\
\text { dentro de diez dias". }\end{array}$ & $\begin{array}{l}\text { En el Capitulo III, De } \\
\text { la Cámara de } \\
\text { Apelaciones Artículo } \\
\text { 20.- “... antes de ocho } \\
\text { dias debe hacérsele } \\
\text { saber la causa de su } \\
\text { prisión, tomársele su } \\
\text { confesión y ponerse } \\
\text { comunicado si no es } \\
\text { que lo embarace } \\
\text { alguna justa causa; y } \\
\text { en este caso debe } \\
\text { ponerse en su noticia } \\
\text { este motivo. }\end{array}$ & \\
\hline $\begin{array}{l}\text { 12. Derecho a la } \\
\text { inviolabilidad } \\
\text { domicilio. }\end{array}$ & $\begin{array}{l}\text { Artículo XVI.- Se } \\
\text { respetará el derecho } \\
\text { que los ciudadanos } \\
\text { tienen a la seguridad } \\
\text { de sus personas, } \\
\text { casas, efectos y } \\
\text { papeles". }\end{array}$ & $\begin{array}{l}\text { Título Primero Artículo } \\
5^{\circ} \text {.- La casa y papeles } \\
\text { de cada individuo son } \\
\text { sagrados, y, esta ley } \\
\text { sólo podrá } \\
\text { suspenderse en los } \\
\text { casos urgentes en que }\end{array}$ & $\begin{array}{l}\text { Capitulo } I V \\
\text { Articulo 210.- Cuando } \\
\text { las circunstancias del } \\
\text { delito pidan el } \\
\text { allanamiento de } \\
\text { alguna casa, el juez lo }\end{array}$ \\
\hline
\end{tabular}




\begin{tabular}{|c|c|c|c|}
\hline & & lo acuerde el Senado & hará por sí mismo. \\
\hline $\begin{array}{l}\text { 13. Derecho a la honra } \\
\text { para los familiares del } \\
\text { delincuente. }\end{array}$ & $\begin{array}{l}\text { XXII. "La infamia } \\
\text { afecta a las penas no } \\
\text { será transcendental a } \\
\text { los inocentes" }\end{array}$ & $\begin{array}{l}\text { Título Primero... } \\
\text { Artículo 17. "Todo juez } \\
\text { puede ser recusado } \\
\text { con arreglo a las } \\
\text { leyes". } \\
\text { Capítulo III, Título V, } \\
\text { De la Autoridad } \\
\text { Judicial. "Artículo 24. } \\
\text { ․ y la pena infame } \\
\text { aplicable a un } \\
\text { delincuente no será } \\
\text { trascendental a su } \\
\text { familia } \\
\text { descendencia". }\end{array}$ & $\begin{array}{l}\text { Capitulo IV } \\
\text { Articulo 214.- Ninguna } \\
\text { pena será } \\
\text { transcendental al que } \\
\text { no tuvo parte en el } \\
\text { delito. }\end{array}$ \\
\hline $\begin{array}{l}\text { 14. Derecho a velar por } \\
\text { la imparcialidad del } \\
\text { juez que conoce y falla } \\
\text { el proceso }\end{array}$ & $\begin{array}{l}\text { Artículo } \\
\text { Ninguno será penado } \\
\text { sin proceso } \\
\text { sentencia conforme a } \\
\text { la ley. }\end{array}$ & $\begin{array}{lr}\text { Título } & \text { Primero, } \\
\text { Capítulo } & \text { Primero, } \\
\text { artículo 17: “Todo juez } \\
\text { puede ser recusado } \\
\text { con arreglo a las } \\
\text { leyes". }\end{array}$ & 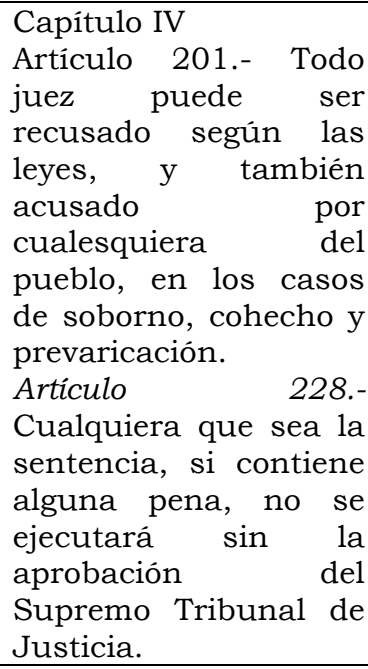 \\
\hline $\begin{array}{l}\text { 15. Derecho a no } \\
\text { sufrir penas } \\
\text { desproporcionadas }\end{array}$ & $\begin{array}{l}\text { XXI. "Las } \begin{array}{r}\text { prisiones } \\
\text { lugares }\end{array} \\
\text { serán } \\
\text { cómodos, y seguros } \\
\text { para la detención de } \\
\text { personas contra } \\
\text { quienes } \\
\text { fundados motivos de } \\
\text { recelo; y mientras } \\
\text { duren estos; y de } \\
\text { ningún modo servirán } \\
\text { para mortificar } \\
\text { delincuentes". }\end{array}$ & & $\begin{array}{l}\text { Capitulo IV } \\
\text { Artículo 218: "Las } \\
\text { penas serán siempre } \\
\text { evidentemente } \\
\text { necesarias, } \\
\text { proporcionadas al } \\
\text { delito y útiles a la } \\
\text { sociedad: en lo posible } \\
\begin{array}{l}\text { correccionales y } \\
\text { preventivas de los } \\
\text { crimenes". }\end{array}\end{array}$ \\
\hline $\begin{array}{l}\text { 16. Derecho a no ser } \\
\text { obligado a declarar } \\
\text { bajo juramento sobre } \\
\text { hecho propio. }\end{array}$ & & $\begin{array}{l}\text { Capitulo III, Título V, } \\
\text { De la Autoridad } \\
\text { Judicial: "Artículo } 24 . \\
\text { Se formarán como } \\
\text { hasta aquí se han } \\
\text { observado las causas } \\
\text { criminales, } \\
\text { excepción que no } \\
\text { recibirán juramento a } \\
\text { los reos para sus } \\
\text { confesiones y cargos, } \\
\text { careos ni otras } \\
\text { diligencias que tengan } \\
\text { tendencia a indagar de } \\
\text { ellos mismos sus }\end{array}$ & $\begin{array}{l}\text { Capitulo } I V \\
\text { Articulo 212.- A ningún } \\
\text { reo se le recibirá } \\
\text { juramento para dar su } \\
\text { confesión, y en ésta no } \\
\text { se hará cargo que no } \\
\text { resulte del sumario, } \\
\text { evitando siempre } \\
\text { preguntas capciosas. }\end{array}$ \\
\hline
\end{tabular}




\begin{tabular}{|c|c|c|}
\hline & delitos; & \\
\hline $\begin{array}{l}\text { 17. Derecho a que la } \\
\text { causa sea tramitada } \\
\text { sin dilaciones }\end{array}$ & & \begin{tabular}{llr}
\multicolumn{2}{l}{ Capítulo IV } \\
Artículo 211.- & Los \\
jueces & son \\
responsables de & la \\
dilación de & los \\
términos prevenidos \\
por las leyes.
\end{tabular} \\
\hline $\begin{array}{l}\text { 18. Derecho a conocer } \\
\text { los fundamentos o } \\
\text { motivaciones de la } \\
\text { sentencia }\end{array}$ & & 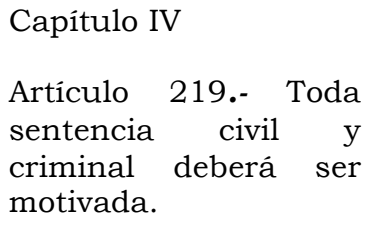 \\
\hline $\begin{array}{l}\text { 19. Derecho a la } \\
\text { defensa y a interrogar } \\
\text { a los testigos }\end{array}$ & & 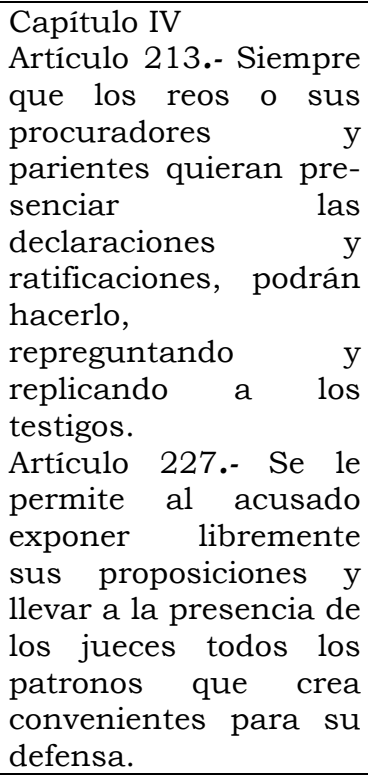 \\
\hline
\end{tabular}

Es evidente, respecto de casi la mayoria de las regulaciones, el mejoramiento que va experimentando entre los años de 1812-1822 la técnica legislativa y el contenido normativo en términos de protección.

La Constitución de 1822 puede ser calificada como más protectora del debido proceso de ley y de las garantías del proceso penal. Instituciones relevantes como la del juez natural, la exigencia de motivación de la sentencia, el derecho a la defensa y a la conducción expedita del proceso penal, por señalar algunos avances, muestran a una Constitución de 1818 como más débil en esta materia.

Llama la atención que no obstante el mejoramiento notable en la Constitución de 1822 de las regulaciones en favor del preso, reo y condenado, haya desaparecido el principio de inocencia consagrado en la carta de 1818, asi como reducido las exigencias respecto de las cárceles para efectos de la seguridad del preso, así como la falta de reglas en materia de incomunicación y las reglas relativas a las probanzas requeridas para iniciar un proceso, sin embargo, en este último caso la carta de 1822 introduce la distinción entre delito in fraganti y no infraganti. 
El Ejecutivo está más limitado en la Constitución de 1822 en sus facultades para afectar la libertad y seguridad de los individuos, al estarle prohibido arrestar a nadie.

\subsection{Regulación del proceso de creación de ley}

La materia no fue regulada en la carta de 1812. La Constitución de 1818 estableció en el Título Tercero, Capítulo Primero, Artículo Único, De la Potestad Legislativa, que correspondia a la "Nación Chilena reunida en sociedad, por un derecho natural... dictar las leyes que le han de regir -lo que ha de hacer- por medio de sus diputados reunidos en Congreso".

En tanto se reunía dicho Congreso la Constitución otorgó limitadamente al Senado (cuerpo colegiado elegido por el Director Supremo) la facultad de legislar en el Título III, capítulo III, artículo 6: "Toda nueva ley o reglamento provincial que haga el Senado; toda abolición de las leyes incompatibles con nuestra independencia; toda reforma o nuevo establecimiento en los distintos cuerpos, institutos, departamentos y oficinas del Estado, como también las adiciones y correcciones de los reglamentos que han regido y rigen, se consultarán, antes de publicarlos, con el Supremo Director, quien en el término de ocho días, a más tardar, deberá expresar su consentimiento o disenso para su publicación, exponiendo oficialmente al Senado las razones fundamentales para su oposición”.

La intervención del jefe del Ejecutivo en el proceso de formación de la ley, constituía una anormalidad ante la precisa declaración del capítulo sobre la potestad legislativa.

Esto permite entender que el veto del Director a la propuesta del Senado fuese establecido con carácter de relativo. Si revisada por tercera vez la oposición del Director el Senado insistiere en su propuesta debia la misma publicarse como ley con el siguiente encabezado: "El Excmo. Supremo Director del Estado, habiendo recibido del Excmo. Senado la resolución siguiente".

Asimismo dentro de las prohibiciones del Ejecutivo señaladas en el Título IV, Capítulo II se dispuso en el artículo 7: "No podrá variar las ordenanzas que han regido y rigen en los cuerpos, departamentos y oficinas de todos los ramos del Estado. Si los jefes de ellos, enseñados por la experiencia, estuvieren plenamente convencidos de la necesidad de alguna reforma, ocurrirán al Senado, el que no innovará cosa alguna, si no tiene pleno conocimiento de la necesidad del remedio; y en este caso procederá conforme a lo prevenido en el tít. III, cap. III, art. 6".

La Constitución entregó al Senado de modo privativo la interpretación de la normativa y el salvar los vacíos legales, así se desprende del Título Tercero, Capítulo III, Artículo 7: "En los casos particulares que ocurran sobre la inteligencia de lo ya establecido o que nuevamente se estableciere, o en defecto de prevención en cualquier estatuto, reglamento, etc., que el Senado diere, resolverá él por sí sólo las dudas".

En la Constitución de 1822 desapareció la relación entre soberanía y actividad legislativa establecida en la Carta Fundamental anterior. Ello puede entenderse a la luz del establecimiento en este año de 1822 de un Congreso bicameral en el que existe un órgano, el Senado, que no es electo popularmente, y cuya composición recuerda al Senado de la Carta de Bayona. 
En todo caso en el Capítulo IV De las facultades del Congreso, artículo 47 se dispuso: "Corresponde al Congreso. 1. Dictar todas las leyes convenientes al bien del Estado... 32. Interpretar, adicionar, derogar, proponer y decretar las leyes en caso necesario".

En el capítulo $\mathrm{V}$ se reguló por primera vez en la historia constitucional chilena republicana el proceso de formación de las leyes ("Modo de formar las leyes, sancionarse y promulgarse").

\subsection{Posición del Ejecutivo en relación con los demás poderes y órganos estatales}

La Carta de 1812 organizó un ejecutivo colegiado mientras que en 1818 y 1822 uno de tipo unipersonal.

En 1812 se dispuso que si faltaba un miembro de la Junta Ejecutiva (Superior Gubernativa) debía elegirse su reemplazante por suscripción. En las cartas de 1818 y 1822 corresponde al legislativo nombrar al reemplazante.

La Carta de 1818 estableció que la elección del Director Supremo “...se deberá hacer sobre el libre consentimiento de las provincias, conforme al reglamento que para ello formará la potestad legislativa". La de 1822 dispuso la elección del Director Supremo por el Congreso. La normativa estableció que juntó con la aprobación de la carta resultaría elegido O`Higgins, quien gobernaría por 6 años de acuerdo con la normativa de los artículos 81 a 84 .

En 1818 no se fijó término al mandato del Director Supremo, no así en la Constitución de 1822, según acabamos de ver.

En los artículos 99, 102, 103 y 108124, se le dieron atribuciones que debilitaban el principio de división de poderes.

La Junta Superior Gubernativa de 1812 requería del dictamen del Senado para "resolver en los grandes negocios que interesen la seguridad de la Patria". El artículo VIII dispuso: "Por negocios graves se entiende: imponer contribuciones; declarar la guerra; hacer la paz; acuñar moneda; establecer alianzas y tratados de comercio; nombrar enviados; trasladar tropas, levantarlas de nuevo; decidir las desavenencias de las provincias entre sí, o con las que están fuera del territorio; proveer los empleos de Gobernadores y jefes de todas clases; dar patentes de corso; emprender obras; crear nuevas autoridades; entablar relaciones exteriores; y alterar este Reglamento". Agregando: "las facultades que no le están expresamente declaradas en esta Constitución, quedan reservadas al pueblo soberano".

El Capítulo III, artículo 4 de la Carta de 1818 dispuso: "Artículo $4^{\circ}$.- Sin el acuerdo del Senado a pluralidad de votos, no se podrán resolver los grandes negocios del Estado, como imponer contribuciones, pedir empréstitos, declarar la

124 “Artículo 99. Él solo librará contra la caja nacional, y no se ejecutará sentencia alguna contra el Fisco, sin su "cúmplase'; Artículo 102. Con aprobación del Poder Legislativo dará los reglamentos que estime necesarios para la ejecución de las leyes; Artículo 103. Todas las provisiones de los Tribunales de Justicia se despacharán a nombre del Supremo Director; Artículo 108. Podrá el Director suspender las ejecuciones capitales, y conmutar penas, si mediare algún grave motivo, obrando de acuerdo con el Supremo Tribunal de Justicia; pero no concederá indultos generales sin aprobación del Poder Legislativo". 
guerra, hacer la paz, formar tratados de alianza, comercio, neutralidad; mandar embajadores, cónsules, diputados o enviados a potencias extranjeras; levantar nuevas tropas o mandarlas fuera del Estado, emprender obras públicas y crear nuevas autoridades o empleos".

Respecto de 1812 se innova al agregar pedir empréstitos, enviar tropas fuera del Estado, crear nuevos empleos públicos; pero se eliminan las patentes de corso, acuñar moneda, proveer los empleos de gobernadores y jefes de todas clases.

Como atribuciones privativas estableció el Título IV Capítulo Primero Artículo $5^{\circ}$.- "El mando y organización de los ejércitos, armada y milicias, el sosiego público y la recaudación, economía y arreglada inversión de los fondos nacionales, son otras tantas atribuciones de su autoridad"; "Artículo 9.- Cuidará del fomento de la población, del de la agricultura, industria, comercio y minería, arreglo de correos, postas y caminos; Artículo 10.- Es privativo del Supremo Poder Ejecutivo el nombramiento de los Secretarios de Estado, de Gobierno, Hacienda y Guerra, quien será responsable del nombramiento, como éstos de sus respectivos empleos". El artículo 19 le encargó la "superintendencia general de todos los ramos y caudales del Estado" y en consonancia con ello se dispuso que las: "sentencias contra el Fisco no serán ejecutadas sin mandato expreso del Director".

Se le dieron atribuciones en materia procesal penal: "Artículo 21. Podrá confirmar o revocar con arreglo a ordenanza, en último grado, las sentencias dadas contra los militares en los consejos de guerra. Artículo 22.- Tendrá facultad de suspender las ejecuciones capitales ordenadas, y conceder perdón o conmutación de pena".

El artículo 16 estableció, en consonancia con las ideas políticas de O’Higgins: "Tendrá el Director especial cuidado de extinguir las divisiones intestinas, que arruinan los Estados, y fomentar la unión que los hace impenetrables y felices".

Un capítulo del Reglamento Constitucional Provisorio reguló los "Límites del poder ejecutivo", que estaban referidos a la prohibición de conocer en causas civiles y criminales y alterar el sistema judicial; al establecimiento de requisitos para el nombramiento de raciones, canonjias o prebendas y ascensos en el cabildo eclesiástico; la detención sin orden judicial por más de 24 horas, rodeando de requisitos esta detención; la prohibición de interceptar la correspondencia epistolar de los ciudadanos; la imposibilidad de proporcionar empleo público a quien no era ciudadano chileno residente; la de dar órdenes sin la respectiva firma del Secretario de Estado; la de no "variar las ordenanzas que han regido y rigen en los cuerpos, departamentos y oficinas de todos los ramos del Estado".

Se dispuso que: "La capital y todas las ciudades y villas del Estado, luego que el Senado de acuerdo con el Director lo tengan por conveniente, harán la elección de sus Gobernadores, Tenientes y Cabildos, conforme al reglamento que para este efecto deberá metodizar el Senado", sin embargo, "Los Gobernadores militares de Valparaíso, Talcahuano y Valdivia, serán elegidos por el Director, y durarán igualmente tres años en sus empleos”. 
Se le facultó para designar los individuos que han de componer la Cámara de Apelaciones y el Supremo Tribunal Judiciario. En caso de vacantes ha de preceder propuesta en terna del cuerpo.

Por su parte la Constitución de 1822 reguló en su Título III Del Gobierno y de los ciudadanos, Capítulo I, el Gobierno, estableciendo que "El Gobierno de Chile será siempre representativo, compuesto de tres poderes independientes: Legislativo, Ejecutivo y Judicial". Agregó el artículo 13. El Poder Legislativo reside en un Congreso, el Ejecutivo en un Director, y el Judicial en los Tribunales de Justicia.

El Congreso contempló una Cámara de senadores en la cual obraban los ministros de Estado y tres generales designados por el Ejecutivo.

Los diputados juraban desempeñar su cargo ante el Director Supremo, el Supremo Tribunal de Justicia y la Corte de Representantes.

La Constitución de 1822 fortaleció la posición del Congreso al señalar en el artículo 47 un conjunto de materias que eran de su competencia ${ }^{125}$.

Se facultó al Poder Ejecutivo "promover en cualquiera de las Cámaras la iniciativa de una ley; pero no presentará extendido el proyecto de ella".

En lo tocante al Ejecutivo se dispuso el tratamiento de Excelencia Suprema, y honores de capitán general de Ejército. Su elección dejó de ser directa: "La elección y reelección se hará por el Congreso en sesión permanente, reuniéndose ambas Cámaras en la sala del Senado al siguiente día de su instalación...se procederá a la elección por votos secretos, y resultará electo el que obtenga los sufragios de las dos terceras partes de los Diputados y Senadores existentes y no licenciados, pudiendo recaer la elección en uno de ellos".

Se le otorgó por el artículo 102 la potestad reglamentaria para la ejecución de las leyes.

125 "Artículo 47.- Corresponde al Congreso: 1. Dictar todas las leyes convenientes al bien del Estado; 2. Fijar las contribuciones directas e indirectas, y aprobar su repartimiento; 3. Declarar la guerra, a propuesta del Poder Ejecutivo; 4. Procurar la paz y aprobar sus tratados; 5. Ratificar los tratados de alianza, comercio y neutralidad, que proponga el Ejecutivo; 6. Cuidar de la civilización de los indios del territorio; 7. Disponer que se manden agentes diplomáticos, u otros Ministros a potencias extranjeras; 8. Establecer la fuerza que necesite la nación en mar y tierra; 9. Dar las ordenanzas para el Ejército, Milicia y Armada; 10. Levantar nuevas tropas; 11. Mandarlas fuera del Estado; 12. Recibir tropas extranjeras, o permitirles tránsito; 13. Crear nuevas autoridades o empleos, y suprimir los establecidos; 14. Examinar la inversión de los gastos públicos; 15. Reglar el comercio, las aduanas y aranceles; 16. Decretar la adquisición o enajenación de bienes nacionales; 17. Hacer efectiva la responsabilidad de los empleados públicos; 18. Aprobar los reglamentos para la administración en todos ramos; 19. Dar el plan general de educación pública; 20. Determinar el valor, espesor, tipo y peso de las monedas; 21. Fijar los pesos y medidas; 22. Recibir empréstitos en casos muy urgentes; 23. Proteger la libertad de la imprenta; 24. Procurar se generalice la ilustración; 25. Hacer todos los establecimientos, que conduzcan al bien de la Nación; 26. Proteger el fomento de la agricultura, de la industria, del comercio y de la minería; 27. Amparar la libertad civil y de las propiedades; 28. Demarcar el territorio del Estado, los limites de los departamentos, situar las poblaciones y titularlas; 29. Conceder, en casos muy útiles a la Nación, privilegios exclusivos por tiempo determinado; 30. Señalar pensiones, gratificaciones y sueldos, a propuesta del Ejecutivo; 31. Nombrar el Director del Estado en los casos de nueva elección, y poder reelegirlo una sola vez; 32. Interpretar, adicionar, derogar, proponer y decretar las leyes en caso necesario." 
Desapareció tanto de la carta de 1818 como de la de 1822 la regla según la cual "las facultades que no le están expresamente declaradas en esta Constitución, quedan reservadas al pueblo soberano".

La Carta de 1818 estableció por primera vez un conjunto de prohibiciones para el ejecutivo, regulación que se mantuvo en el año de 1822, pero, reconociendo esta vez una mayor injerencia del congreso o del senado ${ }^{126}$. Se dispuso en el artículo 118: "Por ningún caso impedirá la reunión del Congreso en los tiempos señalados ni pondrá trabas a sus discusiones que deberán ser enteramente libres: si alguno le influyere lo contrario, será tenido por reo de alta traición a la Patria, sin que su delito prescriba en tiempo alguno".

De la comparación de ambas cartas no se puede colegir de modo diáfano que hay una mayor concentración de poder en manos del Director Supremo. Se le entregan más facultades, pero, también varias de ellas requieren del concurso del Congreso o del Senado. No podría afirmarse con absoluta certeza que el nuevo orden constitucional profundiza la omnipotencia del ejecutivo, sin embargo, el que O’Higgins renovará su mandato por seis años más con posibilidad de reelección por otros cuatro, es una señal clara de una aspiración a consolidar y proyectar su poder político.

Un balance comparativo permite concluir que la Carta de 1818 contiene mejoras sustantivas en lo relativo a la posición del individuo ante la autoridad estatal, que favorecian sus libertades civil y politica. Puede sostenerse que la demanda del cabildo de Santiago de establecer un marco jurídico al ejercicio del poder, significó el surgimiento de un orden constitucional que superaba al Reglamento Constitucional Provisorio de 1812 y la situación generada por la propia elite al otorgar poderes de una dictadura al Gobierno de O`Higgins. El texto de 1822 expresa en buena medida la evaluación de las virtudes y defectos del orden constitucional provisorio, y exhibe algunos avances en el control que la elite pretendió respecto del quehacer del Director Supremo.

La experiencia constitucional acumulada indicaba que generar una institucionalidad con instituciones que compartian el poder, configuraba limites al ejercicio del poder discrecional y arbitrario.

Desde el punto de vista del ciudadano activo, pero, no comprometido en la acción política, las constituciones de 1818 y 1822 aseguraban en buena medida sus bienes más preciados: seguridad personal, libertad, propiedad.

Vista la carta desde el punto de vista de la relación entre las fuerzas y actores políticos relevantes (cabildo de Santiago, ejército del Sur, O`Higgins) el texto no supuso la imposición del patriciado sobre el Director, y la prolongación de su gobierno por seis años (extensibles a 10) generó profundo malestar en las fuerzas conservadoras y exaltadas.

¿Por qué se declaró subsistente la Constitución Provisoria de 1818 luego de la abdicación del prócer? No se ha reparado hasta ahora en este fenómeno jurídico político para evaluar el Gobierno de O`Higgins y a la propia constitución.

126 "Artículo 109.- Observará la más rigorosa economía de los fondos públicos, no aumentando gastos, sino en casos muy precisos, y con aprobación del Poder Legislativo"; Artículo 111.- No creará nuevos empleos, juntas ni comisiones gravosas a la Hacienda, sin aprobación del Poder Legislativo; Artículo 113.- No podrá abrir empréstitos ni exigir nuevas contribuciones directas ni indirectas bajo de ningún pretexto, sin que se aprueben y fijen por el Poder Legislativo". 
Cabría sostener que ello ocurrió porque se puede distinguir el orden constitucional del régimen político, y porque no se atribuyó a la Constitución Provisoria una contribución decisiva para la implementación del régimen calificado como arbitrario y despótico, de hecho, el conflicto entre el Senado (que había sido designado por el propio prócer) y el Director Supremo, constituía una experiencia concreta de la constitución como límite jurídico del poder. Requería, sin embargo, de voluntad politica y apropiación de las prerrogativas. Dicho de otra manera, el orden constitucional parecía contribuir a encauzar el "régimen de la dictadura", que se concibió como un medio para alcanzar bienes mayores como la independencia, la soberanía y las libertades civiles y politicas. La Constitución se mostró útil para poner en cintura a "dictadores".

Resulta relevante además en esta constatación, que dichas limitaciones no le son ajenas a O`Higgins desde el punto de vista de sus ideas políticas y jurídicas, a las que no renunció según se ve en la Carta de 1822, pero que fueron tensionadas por las responsabilidades politicas que asumió y las profundas y peligrosas enemistades que generó. La actividad política, los valores e intereses que se pusieron en juego tuvieron una importante cuota de responsabilidad en que Bernardo O`Higgins, en defensa de su propia visión, adoptara decisiones que en alguna medida pugnaban con sus ideas. La doctrina política y constitucional o'higginiana iluminó la lucha del prócer y sus convicciones sobre la legitimidad del gobierno representativo, pero, en la medida que la lucha política implicó una guerra civil, el sentido de realidad, el pragmatismo político, generó un espacio de acción política que no se midió con la vara de la coherencia con la doctrina politica o constitucional, sino, con la de la sobrevivencia y la imposición sobre el enemigo político: la guerra de independencia y la guerra civil que generó, demostró ser un obstáculo a ratos insalvable para la configuración de una cultura constitucional reflejo de la doctrina de quienes se esforzaban por pasar del despotismo monárquico al gobierno representativo constitucional.

\section{REFLEXIONES FINALES}

El Reino de Chile contó con la persona de Bernardo O`Higgins, uno entre varios destacados dirigentes politicos, para asumir la conducción del proceso que a partir de 1814 llevaría a la independencia de la Monarquía española, y la conformación del Estado y República independiente de Chile. El año 1818 el prócer alcanzó la anhelada meta proclamando la independencia. Seguidamente, estando todavía parte del territorio en manos de la Corona y tensionada la naciente república por luchas intestinas por el poder, promulgó la primera constitución de la república independiente de Chile, la Constitución Provisoria de 1818.

O`Higgins asumió la responsabilidad de darle una dirección al proceso independentista, debiendo resolver qué tipo de Estado, qué tipo de Gobierno y qué características tendrían las relaciones entre estado-individuo y entre los mismos individuos. Es perfectamente distinguible a propósito de estas materias, el ideario del Director Supremo en materia politica y en el plano constitucional, además, su visión se puede diferenciar de lo que fue su práctica política y constitucional. Mientras sus ideas surgen al calor de su propio proceso de vida en Europa y en contacto con intelectuales de la talla de Francisco de Miranda, su práctica estuvo determinada por dicha visión y los intereses y valores de los 
individuos y colectivos que entraron en conflicto en la guerra de la independencia.

Su ideal de Estado y de gobierno, lo ubican dentro del grupo de liberales próximos a un liberalismo de izquierda que repudió la monarquía constitucional, y optó por organizarse bajo un gobierno representativo no hereditario. O’Higgins repudiaba la aristocracia, reconocía y amparaba el mérito; limitó los mayorazgos; consagró y amparó la libertad parcial de los esclavos; permitió actos que implicaban un grado de tolerancia religiosa; fomentó la educación; eliminó la institución inquisitorial; diseño constitucionalmente un Estado activo en favor de la educación pública y la atención de los menesterosos.

Hay una distancia entre el discurso privado y público de O`Higgins y su práctica política. Primero por voluntad de la elite de Santiago de Chile, y luego por decisión propia, el prócer asumió la forma de gobierno dictatorial y ejerció el poder con un amplio margen de libertad.

La historiografia mayoritaria describe, a veces de manera confusa, su gobierno como dictatorial. Es preciso distinguir dos momentos en su gestión gubernamental. En una primera fase la situación de guerra y la incógnita sobre el éxito del proceso independentista, mueve a la propia elite a entregarle la suma total del poder. Lo instaura como dictador (que no tirano). Luego, ante lo que cierto grupo de la elite considera excesos, el Director responde a la demanda por el establecimiento de límites a su "poder dictatorial" y dicta la Constitución Provisoria de 1818.

Bajo el imperio de la Constitución la forma gubernativa de la dictadura ya no tiene lugar. La Carta regula el derecho constitucional de excepción y la figura jurídica de la dictadura no es una opción. Sin embargo, el escenario político no ha cambiado pues sigue siendo de guerra, de amenazas externas y de divisiones internas. Todo lo cual es evaluado por O`Higgins y sus seguidores como una situación de riesgo para consolidar la independencia. Entendió entonces el Director Supremo que podía, dada la situación de hecho, seguir ejerciendo el poder de manera omnímoda, colisionando su voluntad con la institucionalidad que se había creado por demanda de la elite santiaguina, precisamente para limitar el ejercicio del poder por el Ejecutivo.

Dicho de otra manera, O`Higgins trasladó la lógica de la guerra desde el campo de la lucha por la Independencia al campo de la lucha por la organización del Estado independiente: como consecuencia de la comprensión de la oposición como un adversario militar y político, hizo política del mismo modo en cómo hizo la guerra.

La constitución operó como norma jurídica limitando el "accionar dictatorial" de O’Higgins: en la medida que su conducta era táctica y no fruto de sus convicciones políticas liberales y constitucionales, el prócer cedió en más de una ocasión ante el mandato constitucional y ante la interpretación que el Senado Conservador hizo de sus propias atribuciones y de las del Ejecutivo.

Así las cosas, la Constitución Provisoria de 1818 es relevante porque en medio de la guerra por la independencia y las graves divisiones internas, se configuró como un límite a la forma gubernativa de la dictadura (figura políticojurídica invocada por la elite santiaguina) y al intento de "dictadura política" (práctica o’higginista). 
La práctica constitucional de O`Higgins validó en la sociedad chilena un nuevo tipo de ordenamiento jurídico, respecto del cual se carecía de toda experiencia y que se mostraba, sin embargo, con capacidad de orientar las conductas de los gobernantes y de los gobernados. La violación de la norma no es obstáculo para sostener esta idea de la aplicabilidad de la Constitución de 1818. De hecho, luego de la crisis de 1823, y de la pérdida de vigencia de la Constitución de 1822, se la declaró subsistente.

Por otra parte, la Constitución de 1818, la primera del estado independiente, desplegó el ideario liberal y del constitucionalismo al regular por primera vez los derechos individuales de manera extensa; establecer deberes del Estado para con las clases populares; disponer la división de poderes; señalar límites al ejercicio de la autoridad del Ejecutivo en relación con la vida, la libertad y los bienes de la persona del procesado; establecer la responsabilidad por violación de la constitución; regular el derecho constitucional de excepción; y establecer un catálogo de virtudes políticas y privadas a practicar por los chilenos.

La comparación del texto de 1818 con la carta constitucional chilena de 1812, y con la segunda constitución promulgada por O`Higgins, la de 1822, permite delinear con claridad la identidad de la Carta Fundamental y la evolución que experimentó el fenómeno constitucional entre 1812 y 1822. Decimos bien, evolución, porque las disposiciones constitucionales no retroceden, salvo casos excepcionales, ni en el reconocimiento de derechos ni en los mecanismos que contribuyen a entender la Constitución como norma jurídica vinculante, por cuya violación se incurre en responsabilidad

La dimensión política del accionar de O`Higgins no fue obstáculo, no obstante el choque de los grupos en pugna, para que se fuese configurando un orden constitucional que progresivamente se acercaba al ideario que inspiró al mismo prócer.

De esta manera llegó a ocurrir que el ordenamiento constitucional aprobado por el Director Supremo, fue invocado para sostener que su accionar, estando vigente ya la Constitución, era del tipo despótico. Hecha la constatación la elite procuró encauzar su quehacer y poner freno a lo que se experimenta por sus opositores como opresión, jugando las constituciones de 1818 y de 1822 en esta dialéctica política, un rol en favor de una fórmula política que limitaba el ejercicio del poder de quien fue calificado como dictador y caudillo politico.

\section{BIBLIOGRAFÍA}

- Casimiro Albano, Memoria del Excelentísimo señor don Bernardo O`Higgins. Capitán General de la República de Chile, Brigadier en la de Buenos Aires, Gran Mariscal en la del Perú y Socio Protector en la Sociedad de Agricultura, Imprenta de la Opinión, 1844.

- Fernando Arrau Corominas, El diputado Bernardo O’Higgins en el Congreso de 1811, Santiago de Chile: Ediciones Biblioteca del Congreso Nacional de Chile, 2009.

- José Aguilar, "Dos conceptos de República”, en José Aguilar y Jorge Rojas edit. El Republicanismo en Hispanoamérica. Ensayos de historia intelectual y política, 
editorial Fondo de Cultura Económica. Centro de Investigación y Docencia Económicas. México, 2002.

- Horacio Aranguiz, "La aplicación de la Constitución de 1818", en Jaime Eyzaguirre, Fernando Silva, Carlos Ugarte, Estudios de Historia de las Instituciones Políticas y Sociales, Editorial Jurídica de Chile, 1966.

-Miguel Luis Amunategui, La Dictadura de O`Higgins, Imprenta. Litografia y Encuadernación, Barcelona, Santiago de Chile, 1853

- Miguel Luis Amunategui Reyes, Don Bernardo O`Higgins Juzgado por algunos de sus Contemporáneos, según documentos inéditos, Santiago de Chile. Imprenta Universitaria, 1917.

- Javier Barrientos, "La constitución de Cádiz en Chile”, en José Antonio Escudero (coord.), Cortes y Constitución de Cádiz, v.3. Espasa Libros. Fundación Rafael del Pino, Madrid, 2011, pp. 674-699.

-Bernardino Bravo, "El primer constitucionalismo en Chile (1811- 1861)", Revista de Estudios Histórico-Jurídicos, vol. XV, Valparaíso, Chile, 1992-1993, pp. 303331.

-Bernardino Bravo, "El Estado en Iberoamérica (siglos XVI al XXI). panorama histórico: jurisdicción, administración y monocracia”, en Revista Chilena de Historia del Derecho, N 24 / 2013-2014, pp. 191-335.

-Roberto Breña, "Ideologia, ideas y práctica politica durante la emancipación de América: panorama del caso novohispano", Historia y Politica, núm. 11, 2004, pp. 9-33.

- Roberto Breña, El primer liberalismo español y los procesos de emancipación de América, 1808-1824. Una revisión historiográfica del liberalismo hispánico, México, El Colegio de México, Centro de Estudios Internacionales, 2006 (versión en línea en file:///C:/Users/Usuario/Downloads/el-primer-liberalismo-espanoly-los-procesos-de-emancipacion-de-america-1808-1824-una-revision-

histoiografica-del-liberalismo-hispanico-876968.pdf

- Fernando Campos Harriet, Historia Constitucional de Chile, Editorial Jurídica de Chile, Santiago de Chile, 1956.

- Sergio Carrasco Delgado, en "Estudio histórico y jurídico acerca de la génesis de los distintos textos constitucionales chilenos", Revista de Derecho, núm. 165, año XLIV (ene- dic. 1977), Universidad de Concepción, pp. 49-73.

-María Victoria Crespo, "Del republicanismo clásico a la modernidad liberal: la gran mutación conceptual de la dictadura en el contexto de las revoluciones hispanoamericanas (1810-1830)", en Prismas, Revista de historia intelectual, $N^{\circ}$ 17, 2013, pp. 67-87, Argentina.

-Antonio Dougnac, "El sistema jurídico indiano en el constitucionalismo chileno durante la Patria Vieja (1810-1814)", en Revista de estudios histórico-jurídicos. n.22, Valparaíso 2000, pp. 225-266. 
-Jaime Eyzaguirre, Historia Constitucional de Chile. Apuntes de clase, Editorial Universitaria, Santiago, 1955.

-Javier Fernández Sebastián (coord., "En busca de los primeros liberalismos iberoamericanos", en La aurora de la libertad. Los primeros liberalismos en el mundo iberoamericano. Marcial Pons, 2012.

- Javier Fernández Sebastián, (Director), Diccionario político y social del mundo iberoamericano La era de las revoluciones, 1750-1850 Fundación Carolina Sociedad Estatal de Conmemoraciones Culturales Centro de Estudios Politicos y Constitucionales. Madrid, 2009.

- Ignacio Fernández Sarasola, "El primer liberalismo en España (1808-1833)", en Historia Contemporánea número 43, 2011, pp., 547-583.

- Luis Galdames, La evolución constitucional de Chile, imprenta Ballcels y Co, Santiago de Chile, 1925

- Alfredo Gómez Alcorta, Francisco Ocaranza y Martín Lara, "Ilustración y modernidad en la figura histórica e intelectual de don Bernardo O’Higgins Riquelme", páginas 51-70, en Epistolario de don Bernardo O’Higgins. Tomo I. editores Alfredo Gómez Alcorta, Francisco Ocaranza, ediciones Universidad Bernardo O`Higgins, Santiago de Chile, 2011.

-Cristián Guerrero Lira, Ulises Cárcamo Sirguiado, 1818 La proclamación de la Independencia de Chile. Historia y Memoria, Realidad y Mito, editorial Historia Chilena, Santiago de Chile, 2018

-Cristián Guerrero Lira, Ulises Cárcamo Sirguiado, "Bernardo O`Higgins entre izquierda y derecha Su figura y legado en Chile. 1970-2008”, en Cuadernos de Historia núm. 39, diciembre 2013, pp. 113-146.

-Julio Heise, O`Higgins forjador de una tradición democrática, s.e., 1975, Santiago de Chile.

-Julio Heise, Años de formación y aprendizajes políticos 1810-1833, Editorial Universitaria, 1978.

-Julio Heise, O`Higgins y la organización de la República, en Revista Chilena de Historia y Geografia, número 146, 1978, pp. 73-92.

-Marco Jamanca Vega, "El liberalismo peruano y el impacto de las ideas y de los modelos constitucionales a inicios del siglo XIX", en Historia Constitucional (revista electrónica), n. 8, 2007. http://hc.rediris.es/08/index.html

- José Victorino Lastarria, "Historia Constitucional del Medio Siglo", en José Victorino Lastarria, Obras Completas, Volumen VII, Santiago de Chile, 1909.

-Leonardo León, Ni patriotas ni realistas. El bajo pueblo durante la Independencia de Chile, 1810-1822. Ediciones de la Dirección de Bibliotecas, Archivos y Museos, 2011.

-Fernando Martínez L, "La Constitución Política del año 1818", Revista Universidad de Chile, N 4, Universidad de Chile, Sede Nuble, 1978, pp. 18-23. 
-Gustavo Montoya, "Pensamiento político de Bernardo Monteagudo. Entre el autoritarismo y la democracia", en Investigaciones Sociales, año V, núm. 8, , Lima, 2001, pp. 81-111.

-Eugenio Orrego Vicuña, El espíritu constitucional de la Administración O`Higgins, Imprenta Cervantes, Santiago de Chile, 1924.

- Eugenio Orrego Vicuña, O`Higgins. Vida y Tiempo, editorial Losada S.A., Buenos Aires, 1957.

-Manuel Ortuño Martínez, "Hispanoamericanos en Londres a comienzos del siglo XIX", en revista Espacio, Tiempo y Forma. Serie V. Historia Contemporánea, t 12, 1999, pp. 45-72.

- Juan Luis Ossa Santa Cruz, "El gobierno de Bernardo O’Higgins visto a través de cinco agentes estadounidenses, 1817-1823", en revista Co-herencia, vol. 13, núm. 25, julio-diciembre, 2016, pp. 139-166.

- Juan Luis Ossa Santa Cruz, Revolución y constitucionalismo en Chile, 18081814, Revista de Historia Iberoamericana, volumen 5, $\mathrm{N}^{\circ}$ 1, 2012, pp., 111-139.

-Eric Palma González, "Reflexiones en torno a una concepción polifacética para una historia del derecho de los siglos XIX y XX”, en Ius et Praxis, Talca, 1997, pp. 325-350;

-Eric Palma González, El derecho de excepción en el primer constitucionalismo español, editorial, Universidad de Valladolid. Secretariado de publicaciones, 2000.

-Eric Palma González, "La crítica liberal a la judicatura del crimen: España 18101812", Anuario Iberoamericano de Historia del Derecho e Historia Contemporánea, págs., 99-114, Santiago de Chile, 2001.

-Eric Palma González, "El estado de sitio en las Cortes de Cádiz y el Trienio Liberal" revista, Investigaciones Históricas: Época moderna y contemporánea, No. 21, 2001, pp. 181-204.

-Eric Palma González ¿Gobierno Portaliano o Gobierno Conservador Autoritario?: de los mecanismos constitucionales para garantizar la eficacia del ejercicio del poder en la constitución de 1833", Revista de Derecho, núm., 13, 2002, pp., 4564.

-Eric Palma González, La Constitucionalización del proceso penal en Chile y sus alcances en la doctrina y la práctica procesal del siglo XIX, Colección de Investigaciones Jurídicas, Universidad Alberto Hurtado, 2004, 117 pp.

-Eric Eduardo Palma G, Estado constitucional Liberal Católico en Chile (18121924) Nueva Historia Constitucional, 2a . edición, Facultad de Derecho, Universidad de Chile. Lom Impresiones, 2012, 743 pp.

-Eric Eduardo Palma G, coord., Abolición de la esclavitud en el constitucionalismo del siglo XIX: Colombia, Chile, Perú y Portugal, Editorial Jurídica de Chile, junio de 2016, 157 pp. 
-Carlos Petit, "negros y mulatos españoles de ambos hemisferios", en Historia Constitucional, n. 15, 2014, pp. 155-204.

-André Pons "Bolivar y Blanco White", Anuario de Estudios Americanos, tomo LV, 2, 1998, pp. 507-529

-Carlos Ramos, La Letra de La Ley. Historia de las Constituciones del Perú, Centro de Estudios Constitucionales, Tribunal Constitucional del Perú, Lima, 2018.

-Demetrio Ramos Pérez, "El proyecto de 1826: una clave en la evolución de Bolivar", Cuadernos Hispanoamericanos, núm. 401 (noviembre 1983), pp. 21-32.

-Juan Carlos Rey González, "De la ilusión republicana a la realidad personalista. Análisis de las ideas, la legislación y la acción en torno a la dictadura y los estados excepcionales a partir del pensamiento de el Libertador", Anuario de Estudios Bolivarianos / Año XII, número 13, 2006, pp. 91-134.

-Jaime E. Rodríguez O, La independencia de la América Española, Editorial Fondo de Cultura Económica, 2 ${ }^{\mathrm{a}}$. ed., y reimpresión, 2010.

-Alcibiades Roldán, "Los desacuerdos entre O`Higgins y el Senado Conservador", en Anales de la Universidad de Chile, Tomo LXXXII, 1892-1893.

-Eduardo Rozo Acuña, Simón Bolivar. Obra política y constitucional, Editorial Tecnos, 2007.

- Alejandro San francisco y Cristina Moyano, "El liberalismo en chile en el siglo XIX. La formación del concepto, su trayectoria y sus dimensiones", en La aurora de la libertad. Los primeros liberalismos en el mundo iberoamericano. Marcial Pons, 2012, pp. 145-180.

-Luis Valencia Aravia, "Apuntes sobre la Politica Constitucional de O’Higgins", Boletín de la Academia Chilena de la Historia, núm., 60, 1959.

-Luis Valencia Avaria, El Pensamiento de O’Higgins. La Pluma y Espada, Editorial del Pacífico, Santiago, 1974

-Luis Valencia Avaria, Orígenes político sociales de las constituciones de O`Higgins, Revista de Derecho Público, núm. 23, 1978, pp. 25-35.

-Joaquín Varela Suanzes-Carpegna, "Retrato de un liberal de izquierda", Historia Constitucional (revista electrónica), n. 5, 2004.

- Joaquín Varela Suanzes-Carpegna, "Algunas reflexiones metodológicas sobre la Historia Constitucional", en Historia Constitucional. Revista Electrónica, número 8, 2007, pp. 246-259.

- Joaquín Varela Suanzes-Carpegna, "Algunas reflexiones metodológicas sobre la Historia Constitucional”, Teoría y Realidad Constitucional, núm. 21, 2008, pp. 411-425.

-Joaquín Varela Suanzes-Carpegna, Historia e historiografia constitucionales. editorial Trotta, Madrid, 2015 
- Benjamín Vicuña Mackenna, Vida del Capitán General don Bernardo O`Higgins, Editorial del Pacífico, Santiago de Chile, 1976, 675 pp

-Alberto Vivar Flores, "El liberalismo constitucional en la fundación del imperio brasileño", en Historia Constitucional (revista electrónica), n. 6, 2005. http://hc.rediris.es/06/index.html

- Francisco Zúñiga Urbina, “Constitución de 1812 y su influencia en el constitucionalismo liberal chileno", en Revista española de la función consultiva, núm. 19, 2013, pp. 677-726

\section{Fuentes Impresas}

-Archivo de don Bernardo O`Higgins. Tomo VII. Editorial Universitaria, Santiago de Chile, 1950.

-Archivo de don Bernardo O’Higgins, Tomo XXXV, Academia Chilena de la Historia, 2001

Archivo de don Bernardo O`Higgins. Tomo XII, Imprenta Universitaria, 1953.

Archivo de don Bernardo O`Higgins. Tomo XIII. Editorial Universidad Católica, 1962;

Constituciones Políticas de la República de Chile 1810 - 2005, Primera Edición (2005), Editado por el Diario Oficial de la República de Chile

-Declaración de la Independencia de Chile. Acta de la Independencia de Chile, Universidad de Concepción, Concepción, 1978.

-Epistolario de don Bernardo O`Higgins. Tomo I. editores Alfredo Gómez Alcorta, Francisco Ocaranza, ediciones Universidad Bernardo O`Higgins, Santiago de Chile, 2011.

-Epistolario de don Bernardo O`Higgins. Tomo II. editores Alfredo Gómez Alcorta, Francisco Ocaranza, ediciones Universidad Bernardo O`Higgins, Santiago de Chile, 2011.

-Gazeta Ministerial de Chile. Santiago, sábado 7 de agosto de 1819, en Archivo de don Bernardo O`Higgins. Tomo XIII. Editorial Universidad Católica., 1962

-Gazeta Ministerial de Chile. Santiago, sábado 2 de septiembre de 1820, en Archivo de don Bernardo O`Higgins. Tomo XIV. Editorial Universidad Católica., 1962

-Manifiesto que hace a las naciones el Director Supremo de Chile de los motivos que justifican su revolución y la declaración de su independencia, versión en linea en https://www.leychile.cl/Navegar?idNorma=1063810

- Valentín Letelier Sesiones de los Cuerpos Legislativos de la República de Chile. 1811 a 1845, Santiago, Imprenta Cervantes (1886-1908) 
LA CONSTITUCIÓN CHILENA DE 1818 (A 200 AÑOS DE SU PROMULGACIÓN) ...

Enviado el (Submission Date): 13/11/2018

Aceptado el (Acceptance Date): 02/01/2019 